NBER WORKING PAPER SERIES

\title{
DISENTANGLING THE IMPORTANCE OF THE PRECAUTIONARY SAVING MOTIVE
}

\author{
Arthur Kennickell \\ Annamaria Lusardi \\ Working Paper 10888 \\ http://www.nber.org/papers/w10888
NATIONAL BUREAU OF ECONOMIC RESEARCH 1050 Massachusetts Avenue
Cambridge, MA 02138
November 2004

We would like to thank Rob Alessie, Erich Battistin, Christopher Carroll, Jeffrey Dominitz, Eric Engen, Michael Haliassos, Erik Hurst, Michael Palumbo, Jon Skinner, Steven Venti, and participants at the NBER Summer Institute, the TMR Conference on Savings and Pensions, Evian, France, the 21st Arne Ryde Symposium on Non-Human Wealth and Capital Accumulation, Lund, Sweden, the Ente Luigi Einaudi for Monetary, Banking and Financial Studies, Rome, Italy, the plenary session at the $27^{\text {th }}$ Conference of the International Association for Research in Income and Wealth, Stockholm, Sweden, for suggestions and comments. Any errors are our responsibility. Ryan Bledsoe and Amber Lytle provided excellent research assistance. Lusardi acknowledges financial support from the Rockefeller Center at Dartmouth College. The opinions expressed in this paper are those of the authors and do not necessarily reflect the views of the Board of Governors of the Federal Reserve System. The views expressed herein are those of the author(s) and not necessarily those of the National Bureau of Economic Research.

(C) 2004 by Arthur Kennickell and Annamaria Lusardi. All rights reserved. Short sections of text, not to exceed two paragraphs, may be quoted without explicit permission provided that full credit, including () notice, is given to the source. 
Disentangling the Importance of the Precautionary Saving Motive

Arthur Kennickell and Annamaria Lusardi

NBER Working Paper No. 10888

November 2004

JEL No. D91, E21, C21

\section{ABSTRACT}

We assess the importance of the precautionary saving motive by relying on a direct question about precautionary wealth from the 1995 and 1998 waves of the Survey of Consumer Finances. In this survey, a new question has been designed to elicit the amount of desired precautionary wealth. This allows us to bound the amount of precautionary accumulation and to overcome many of the problems of previous works on this topic. We find that a precautionary saving motive exists and affects virtually every type of household. Even though this motive does not give rise to large amounts of wealth for young and middle-age households, it is particularly important for two groups: older households and business owners. Overall, we provide strong evidence that we need to take the precautionary saving motive into account when modeling saving behavior.

Arthur Kennickell

Board of Governors of the Federal Reserve System

Mail Stop 180

Washington, DC 20551

arthur.kennickell@frb.gov

Annamaria Lusardi

Graduate School of Business

University of Chicago

5807 S. Woodlawn Avenue

Chicago, IL 60637

and NBER

alusardi@gsb.uchicago.edu 


\section{Introduction}

One of the major innovations of the literature on consumers' behavior has been the theory of precautionary saving. This theory predicts that risk depresses consumption and increases the accumulation of wealth. In some theoretical specifications, the precautionary saving motive is the main reason to hold wealth. Is this true empirically? As illustrated in the first sections of the paper, the empirical work on precautionary saving to date faces several challenges, which ultimately make it very difficult to disentangle the quantitative importance of this motive.

In our work, we adopt a new approach to study the importance of precautionary saving. We rely on a question from the 1995 and 1998 waves of the Survey of Consumer Finances (SCF95 and SCF98 hereafter), where respondents are asked to report directly their desired amount of precautionary wealth. This subjective measure of precautionary accumulation allows us to bound the size of the precautionary saving motive and to overcome many of the problems of previous work on this topic.

We find that a precautionary saving motive exists and affects virtually every household. Thus, models that rely on quadratic preferences or certainty equivalence are not a good characterization of consumers' behavior. But we also find that this motive does not give rise to high amounts of wealth at the aggregate level. Desired precautionary wealth represents approximately 8 percent of total net worth and 20 percent of total financial wealth in the economy. However, we can identify two groups in the population for which the precautionary saving motive is particularly important: older households/cohorts and business owners. These groups alone account for the majority (65 percent) of total desired precautionary wealth. Close examination of both groups suggests that not just income risk but also other risks should be 
taken into account when modeling saving behavior. Because these groups play such a pivotal role, analyses that include or exclude households close to or after retirement and/or business owners are bound to deliver very different estimates of the precautionary saving motive.

Our work provides additional results to assess more accurately households' behavior toward saving. For example, we find there is great heterogeneity in precautionary accumulation, much more than has been reported in previous work. Existing theoretical models need to be enriched to account for the large differences in wealth holdings we observe even within the same observable economic group or class of risk. Furthermore, we find that measures of accumulation, such as liquid or financial net worth, are too restrictive and provide a rather inaccurate account of the stock of resources households have available to buffer themselves against shocks. In addition, our findings help explain both the behavior of families at the bottom of the wealth distribution, where risk interacts with the presence of welfare programs, and the behavior of families at the top of the wealth distribution, where business owners are very prominent.

This paper is organized as follows: In Section 2, we review some of the previous literature on precautionary saving and discuss the problems associated with measuring risk and precautionary wealth. We also outline other pitfalls of the empirical estimates of precautionary accumulation. In Section 3, we describe our alternative approach based on a subjective measure of precautionary wealth and provide our estimates. In Sections 4 and 5, we discuss our findings and provide concluding remarks. 


\section{The Importance of the Precautionary Saving Motive: Review of the Previous Literature}

Theoretical intertemporal models of consumption/saving with income uncertainty predict that precautionary wealth can explain a large share of total wealth accumulation. ${ }^{1}$ For example, Skinner (1988) calculates that about half of household wealth can be explained by precautionary savings due to income risk. Caballero (1991), Cagetti (2000), and Gourinchas and Parker (2002) report similar results. However, the empirical evidence based on micro data yields mixed results. Here we identify three sets of papers, which provide widely differing estimates. The first set, which finds estimates in the lowest range, includes the empirical work of Skinner (1988) and Dynan (1993). Looking across occupation groups to assess the effect of occupation-specific risks, Skinner (1988) finds no evidence that households in riskier occupations save more. Similarly, Dynan (1993) argues the empirical estimates of the coefficient of relative prudence are too small to generate precautionary saving. The second set of papers, including Guiso, Jappelli and Terlizzese (1992), Lusardi (1997, 1998, 2000), and Arrondel (2002), uses subjective measures of income risk and find modest values for precautionary wealth-estimates range from 2 to 8 percent of total household wealth accumulation. The final set of papers, including Dardanoni (1991), Engen and Gruber (2001), Hubbard, Skinner and Zeldes (1995), Carroll and Samwick $(1997,1998)$, and Kazarosian (1997), finds that precautionary savings can explain a sizable share of wealth. For example, according to Carroll and Samwick (1998), up to 50 percent of the wealth of the median household consists of precautionary wealth.

This disturbingly large range of estimates makes it very hard to assess the importance

\footnotetext{
${ }^{1}$ In our analysis, we concentrate mainly on wealth accumulation and we do not study the effect of the precautionary saving motive on consumption, labor supply, or other aspects of economic behavior at the household or aggregate level.
} 
of the precautionary saving motive. Underlying these differences are various sources of data and empirical methodologies. In addition, there are several conceptual issues that affect the ability of the econometrician to estimate the precautionary saving motive as we discuss below. These issues, particularly those related to the measurement of wealth and risk, led us to follow a different approach to assess the importance of the precautionary saving motive, which is reported in Section 3.

\subsection{Pitfalls and Biases in Estimating the Importance of the Precautionary Saving Motive}

Most of the empirical work on precautionary saving has been focused on the estimation of the following equation:

$$
g\left(W_{h}\right)=f\left(\text { risk }_{h}, Y_{h}^{p}, X_{h}\right)
$$

where $W_{h}$ indicates wealth of household $h$, risk is a measure of the risk faced by household $h, Y^{p}$ is permanent income, $X$ is a set of controls for wealth including age, demographics, and other household characteristics, and $g$ and $f$ indicate the functions to measure wealth and the relationship between wealth and the right-hand-side variables respectively. The extent to which wealth increases with risk forms the basis for estimating the importance of the precautionary saving motive.

Several pitfalls and potential biases limit the empirical work using this specification. In this section, we address eight such issues and discuss how they are likely to affect the estimates of the importance of the precautionary saving motive. They guide our approach in finding alternative ways to estimate the size of precautionary savings.

\section{1: The measurement of wealth and risk}


Which measure of wealth should be used in the estimation of precautionary accumulation? This is one of the most critical issues in estimating precautionary savings. The problem is that many components of wealth differ in terms of their liquidity, accessibility, and suitability as collateral against borrowing, among other features. As mentioned in Browning and Lusardi (1996), only under the certainty equivalence model, can we sum across components of wealth. Thus, in a model with precautionary saving, different components of wealth are not perfectly substitutable.

Some authors, such as Engen and Gruber (2001), Hrung (2000) and Alan (2004), have simply considered a measure of liquid wealth (which includes mostly savings and checking accounts, bonds, stocks and short-term debt) when estimating precautionary wealth. However, liquid wealth is a very restrictive measure of accumulation since the large majority of US households hold other assets in their portfolios (Kennickell, Starr-McCluer, and Sundén (1997)). Moreover, households hold relatively little in liquid wealth. Typically, the largest asset among households is housing equity. Given the development of home equity lines of credit, housing wealth has become much more liquid than in the past. However, this development does not mean that housing equity or real estate wealth can be taken as perfect substitutes for liquid assets. There are often transaction costs associated with setting up such loans. In addition, if the house is liquidated quickly, the sales price may be well below a longer-term market value (which approximates what households are asked to report in wealth surveys).

Another large component of wealth, particularly for middle-age and older workers, is designated retirement accounts, such as IRAs and Keogh plans and pension accounts like 
401(k)s. ${ }^{2}$ While there are tax advantages in investing in these assets, the investment is not fully accessible without incurring an early-withdrawal penalty until age $591 / 2$. Thus, one cannot simply use the current market value of these assets (Poterba, (2003)). One component of wealth, that is particularly hard to deal with is business equity. Although entrepreneurs are not a large portion of the population, they hold as much as $40 \%$ of total wealth (Gentry and Hubbard (2004)). Because such wealth is often hard to liquidate and may be difficult to leverage, it is not clear how much of it might be relevant as precautionary wealth. Another important issue is how to treat debt. Most households only need to service their debt. Thus, only the required loan payments over some period need to be netted from assets, rather than subtracting all the short and long term debt.

To summarize: the practice of assigning a weight of one or zero to the individual components of wealth (the function $g$ in the equation above) represents a crude and often inappropriate way to measure household resources. Most importantly, it may lead to misleading estimates of the extent of precautionary accumulation. The idea that precautionary savings may explain a large amount of liquid assets becomes less useful in light of the fact that liquid assets are only a small proportion of a potentially much larger pool of precautionary wealth for many families.

As far as the measurement of risk is concerned, much of the empirical work on precautionary saving has concentrated on one source of risk: income risk. Researchers have modeled a household-specific stochastic process for income and estimated it using panel data.

\footnotetext{
${ }^{2}$ See, among others, Poterba, Venti and Wise (1994). It is worth noting that such tax-preferred accounts defer sometimes substantial amounts of taxes until the point when funds are removed from the accounts. Thus, as an indication of future consumption possibilities, balances in these account are overstated.
} 
The variance of earnings or non-capital income has then been used as a proxy for risk, as in the third set of papers mentioned above that find evidence of sizable precautionary savings. However, there are several shortcomings in this approach. First, it is difficult to distinguish empirically between transitory income and measurement error. Second and more importantly, workers may know more than the econometrician. What is calculated empirically as income variation could potentially be well-known and insured against (Caballero (1991) and Browning and Lusardi (1996)). In principle, subjective measures of income risk obviate many of the problems with estimated income processes, but they often result in very low estimates of income risk.

In addition to income, other risks can also affect household accumulation. Two that have been investigated thus far are longevity risk and health risk, as in Davies (1981), Leung (1994), Starr-McCluer (1996), Hubbard, Skinner, and Zeldes (1995), and Palumbo (1999), among others. These risks, in particular health, are also hard to measure directly, and we do not yet have reliable subjective measures. This list does not exhaust the sources of risks that households can face; interest rate or investment risk and also consumption risk (for example, the risk that durable good break down and should be replaced quickly) can be important for households. These risks are also very hard to measure.

\section{2: Preferences}

The extent of precautionary accumulation depends not just on risk, but also on preferences regarding risk (Caballero (1990, 1991), Cagetti (2000), and Attanasio, Banks, Meghir and Weber (1999)). Another key factor is the rate of time preference (Deaton (1991) and Carroll $(1992,1996))$. However, very few data sets include information on such preferences and those that do show, for example, substantial variation in the coefficient of risk aversion (Barsky, 
Kimball, Juster, and Shapiro (1997)). Assuming the same preferences across the sample can yield, at best, imprecise estimates of the importance of precautionary saving.

Differences in preferences can have other important implications. Workers who are riskaverse may self-select into occupations (or even specific types of employers within industries) that offer job security. If risk aversion is positively correlated with prudence, these workers may also save more. ${ }^{3}$ In this case, there is a likely downward bias in the estimates of the precautionary saving motive, as reported by Lusardi $(1997,2000)$ and Fuchs-Schündeln and Schündeln (2003). Such selection might explain why Skinner (1988) finds no evidence of precautionary savings when examining workers across different occupation groups.

\section{3: Liquidity constraints}

Precautionary accumulation is strongly affected by the presence of liquidity constraints. To the extent that households can borrow, they may not need much wealth to shield themselves against shocks. In fact, theoretical models of precautionary saving do not necessarily predict that wealth will be (strictly) positive; it is possible that risk prevents households from going heavily into debt, but they still do not hold positive amounts of wealth. In many models, there are devices that implicitly or explicitly prevent such behavior. For example, some authors add constraints that disallow negative wealth (Deaton (1992, chapter 6)). Others consider specific characterizations of risk (Carroll (1992)). Differences in borrowing opportunities are very relevant to assess the importance of the precautionary saving motive. However, individual borrowing opportunities are largely unobservable in most data sets.

\section{4: Other forms of insurance}

\footnotetext{
${ }^{3}$ See Kimball (1990), for an explanation of the role of prudence in models of precautionary saving.
} 
Models of precautionary saving rely on the assumption that insurance markets are imperfect or do not exist. While markets can be imperfect, individuals can insure against risk not only by accumulating wealth but also through a network of family and friends or other informal channels. If agents can receive help when they are hit by shocks, they do not need to amass much precautionary savings. Thus, it is critical to differentiate those individuals who have access to sources of help and support (Lusardi $(1998,2000))$. Similarly, there exists insurance offered by the government (unemployment benefits, health and disability insurance, etc). One complication with public insurance in the US is that many welfare programs are means-tested. This creates a strong disincentive to hold wealth, (Hubbard, Skinner and Zeldes (1995)). Consequently, even households facing high risk, particularly those with low permanent income, may find it optimal to hold very little wealth. Thus, there may be severe non-linearities in the relationship between wealth and risk, which highlight the importance of choosing the correct functional form as discussed next.

\section{5: Functional forms}

The relationship between wealth and risk (the function $f$ ) may display a non-linear shape not only because of the behavior of households at the bottom of the wealth distribution, but also because of the behavior of those at the top of the wealth distribution. Households at the top of the distribution are disproportionately business owners, who may display different preferences and face different risks or constraints than more typical households (Hurst and Lusardi (2004)).

The functional form chosen in many studies involves the logarithm of wealth, a transformation which excludes a substantial fraction of the population (9 percent of households 
had net worth of zero or below in SCF98). ${ }^{4}$ This exclusion is highly undesirable. That these excluded households hold no wealth or are in debt may be related to features of the welfare system, individual preferences, or a prior, substantial negative shock. It is hard to argue these characteristics are not correlated with the precautionary motive. Indeed, some of these excluded households are precisely those that may face high risks. As a result, samples with such exclusions are very likely to suffer from a selectivity bias.

\section{6: Macro and past shocks}

While there has been an extensive discussion of the importance of macro shocks in the estimation of Euler equations, ${ }^{5}$ this topic has been largely ignored in the estimation of precautionary saving. It is, nevertheless, important in this context as well. Simply, it is not possible to estimate the extent of precautionary accumulation using a single cross-section of wealth data alone. The problem may be best understood with an example. Suppose that, because of a national housing market bust, the wealth of homeowners was substantially reduced, but only temporarily (the housing market recovers in the future and goes back to the original equilibrium). Suppose further, as it is not unreasonable, that homeowners are less likely to face high earnings risk. Simple regressions of total net worth on income risk lead to biased estimates of the extent of precautionary accumulation. Similarly, during a recession, those households facing high unemployment risk are also those more likely to be hit by shocks that deplete their

${ }^{4}$ See Carroll, Dynan and Krane (2003) for an alternative functional form that does not exclude the zerowealth observations.

\footnotetext{
${ }^{5}$ See the discussion in Browning and Lusardi (1996) and the references therein.
} 
resources. Thus, some high risk households may have temporary low wealth and it is important to account for past shocks (Carroll, Dynan and Krane (2003)).

\section{7: Precautionary saving and portfolio choice}

Risk affects not only wealth but also portfolio choice. Drèze and Modigliani (1972) show that, unless income risk is perfectly insurable, consumption and portfolio decisions are not separable. To date, however, most of the saving and portfolio choice models have been estimated separately. A series of empirical papers has found that agents who face high earnings risk invest less in stocks (Guiso, Jappelli and Terlizzese (1996), Haliassos and Bertaut (1995), and Hochguertel (2003)). Additionally, business owners, although they hold large amounts of wealth, are less likely to invest in publicly traded stocks (Heaton and Lucas (2000)). Stocks, however, were one of the fastest growing components of wealth in the 1990s. Given the extraordinary returns of the stock market in the 1990s, wealth is likely to be very high for households that have invested in stocks. At the same time, many of these same households face low income risk. Again, regressions of wealth on income risk may tell us little about the importance of the precautionary saving motive. Estimates may be particularly sensitive to the inclusion or exclusion of business owners in the sample.

\section{8: Other motives to save}

In addition to the precautionary motive, there are other motives to save, and it may be difficult to disentangle them. For example, entrepreneurs are likely to face very high risk, and thus, would be expected to save more. These households do hold a lot of wealth and mostly in their business(es). However, business wealth may be the reward for work in the business (sometimes as a partial substitute for a salary or pension), a shield against shocks, a current valuation of future profits, or simply the price of independence in work. Similarly, it may be 
hard to disentangle the precautionary saving motive from the bequest motive using wealth data for older households. These households may wish to leave wealth to their heirs, but they may retain their wealth until the end of life in case shocks hit or possibly as an instrument to ensure the attention of the heirs. While many theoretical models of precautionary savings abstract from these and other motives to save, such motives can play an important role empirically. Moreover, the data needed to control for such factors are often not available.

A summary of the aforementioned issues and their effects on the empirical estimates of precautionary wealth is reported in Table 1 . Clearly, some of the problems are interdependent. While their effects may not be equally important, almost all of them present problems for the estimation of precautionary saving using current methods and existing data sets. As the last column of the table outlines, the effects of these issues on the estimates of the precautionary saving motive go in different directions. Thus, it is hard to determine whether current estimates in the literature represent a downward- or upward- biased estimate of the true amount of precautionary wealth.

\section{An Alternative Approach: A Direct Measure of Desired Precautionary Savings}

As the previous section shows, it is at best very difficult—sometimes impossible- to estimate the extent of precautionary accumulation using the methods and types of data that have prevailed in the existing literature. In this paper, we follow a different approach. We rely on a question about precautionary wealth that one of the authors participated in designing for the SCF. Our theoretical frame of reference is the 'buffer-stock' model, which we summarize below as the foundation of the theoretical predictions we exploit in our work. 


\subsection{The "Buffer-Stock" Model of Saving}

The theoretical model that has guided our empirical work is the "buffer-stock" model of saving, as derived by Carroll $(1996,1997)$ and Deaton $(1991)$. These authors consider an intertemporal model of consumption behavior under uncertainty and show that, in their specifications, consumers have a target wealth to income ratio. Consumers want to hold a "buffer-stock" of wealth to insure against risk; when wealth goes below the target, saving will increase, and when wealth is above the target, saving will decrease. As Carroll (1997) argues, this is an appealing feature of the model and may well be aligned with the predictions of many financial planners, who traditionally advise people to hold a certain ratio of wealth to long-run income as precaution against shocks. Similarly and most importantly, Deaton (1992, pages 202203) shows the underlying maximization problem may be quite difficult to solve formally, but simple rules can closely approximate the optimal behavior. Thus, it is not unrealistic to expect households to be able to report the approximate size of the "buffer-stock" they wish to hold.

The model delivers predictions that can be tested empirically. First, the size of the "buffer-stock" households want to hold is a positive function of risk. Not only is risk important, but also preference parameters, such as the degree of impatience play a pivotal role. According to the simulations of Carroll (1997), Carroll and Samwick (1998) and Deaton (1991), when households are impatient, precautionary savings can be relatively small, particularly for younger consumers and up to the age of 50. There is another important prediction: if there is no floor to income, the target level of wealth chosen by consumers is strictly positive; consumers will not let their wealth fall to zero, as there would otherwise be a chance that consumption goes to zero. ${ }^{6}$

\footnotetext{
${ }^{6}$ This no-borrowing behavior has much to do with the assumption about preferences and the fact that the utility function is of the CRRA form. If preferences were of the CARA form, consumers would be willing to let assets
} 
As reported in Sections 2 and 2.1, a great deal of empirical work has attempted to assess the importance of the precautionary saving motive. In this project, we follow a different approach and ask respondents directly about the size of the stock of wealth they would like to hold to shield themselves against shocks.

\subsection{A Direct Measure of Precautionary Savings}

The SCF95 introduced a new question intended to elicit the size of the "buffer-stock" that households would like to hold. ${ }^{7}$ The exact wording of the question is as follows:

\section{"About how much do you think you and your family need to have in savings for unanticipated emergencies and other unexpected things that may come up?"}

This question directly elicits the amount of desired "buffer-stock" savings and provides an alternative way to bound the extent of precautionary accumulation. Much work was devoted to pre-testing the question, assessing whether the question was understood, and identifying the difficulty in answering. ${ }^{8}$ The exact wording of the question also merits consideration. First, the reason for asking households what they "need to have in savings" rather what they have is that

be zero or negative.

${ }^{7}$ This question has been retained in later waves of the SCF. This question has now been added to the 2003 Italian Survey of Household Income and Wealth.

${ }^{8}$ This question is placed after a sequence of questions about saving and planning, and this context was selected specifically to create the correct cognitive framework for respondents to focus on the intent of the question. From the given responses, it appears that respondents did not have much difficulty with the question. In SCF95, only about three percent of the respondents answered "don't know" and were subsequently unable to provide even a range of values upon probing by the interviewer. 
their wealth may be out of equilibrium due to negative or positive shocks. The fact that some households have zero or low actual wealth does not necessarily mean that they do not have a precautionary saving motive; rather they may have faced past shocks. Second, the phrase "unanticipated emergencies and other unexpected things that may come up" mirrors what households most commonly report in open-ended SCF questions concerning current motives to save. In SCF95, over 36 percent of participants gave such a response, as reported in the appendix Table A1. In other surveys that collect similar information on saving motives, such a "precautionary motive" is consistently the most frequently reported saving motive. " "Unforeseen events,"and "emergencies" are the descriptions respondents most often put forward when asked about their motive to save. Third, this measure does not restrict attention to income risk only. There are several advantages to this method. First, it allows us to obtain a householdspecific amount of desired precautionary accumulation directly, thus circumventing the problems of unobservable preferences, borrowing possibilities, and informal or formal insurance schemes (issues 2, 3, and 4 discussed in Section 2.1). Second, our method allows for risks beyond income risk. Third, it measures the amount of "desired" (or equilibrium) precautionary savings rather than the "actual" amount of savings. This is a substantial advantage, particularly in dealing with households that have depleted their precautionary buffer of wealth as a result of past shocks

\footnotetext{
${ }^{9}$ See Kennickell (1995). Alessie, Lusardi and Aldershof (1997) examine the motives to save in the Dutch Socio-Economic Panel and report that the most frequently indicated motive to save is for "unforeseen events." The proportion of respondents choosing this motive remains high and constant over the life cycle. Similar findings are reported when using the Dutch CentERdata panel. In this case, households are asked to report on a scale from 1 to 7 the importance of several motives to save. Of the listed 13 motives, the one that received the highest score was "save as a reserve to cover unforeseen expenses." Similarly, in the new German SAVE survey, households have to rate the importance of 9 saving motives using a scale from 1 to 10 . The motive that was considered most important by nearly all families is "saving as a precaution for unexpected events" (see Börsch-Supan and Essig (2003) for detail). Looking at data for Japan, Horioka, Yokot and Miyaji (1994) find that of the listed 12 motives to save, respondents have chosen most often the precautionary saving motive which is indicated as: "for illness, disasters, and other unforeseen expenditures."
} 
(issue 6). Finally, we avoid the problem of defining what measure of wealth is the appropriate one for gauging the variation in precautionary savings across households (issue 1).

There are also disadvantages in working with such subjective questions. For example, the question may turn out to be difficult for survey participants to understand and may be answered imprecisely. In addition, respondents may consider only their preferences and not think of budget constraints. They may also be led to think of current or small risks; alternatively, they may consider every possible risk over their remaining life but fail to discount the future. Such problems are not unique to our work; they also surface in the literature using subjective measures of income risk. In the following sections, we provide a detailed evaluation of this question and show that these data are not simply noise.

\subsection{Some Descriptive Findings about Desired Precautionary Savings}

Figure 1 reports the density of desired precautionary savings in the total sample using data from SCF95. ${ }^{10}$ We first note that the reported amounts are concentrated in the range of $\$ 5,000$ to $\$ 10,000$. However, a small proportion of households also reports very high amounts of precautionary wealth. Thus, the precautionary saving motive can potentially rationalize high amounts of wealth holdings as well. Figure 1 also shows there is much heterogeneity in saving behavior, even when focusing on the precautionary saving motive alone.

In Figure 2, we overlap the densities of desired precautionary savings from the surveys in 1995 and in 1998 (in 1995 dollars). As the figure shows, the distributions of answers are remarkably similar. This is what we expect empirically, given that it was a period in which

\footnotetext{
${ }^{10}$ For a description of the SCF, see the data appendix.
} 
unemployment risk was rather stable, and there were no major changes, at least at the aggregate level, in health, longevity, or other risks. At the same time, household wealth increased dramatically due to the very high returns in the stock market and housing market, which should not have affected the amount of desired precautionary savings (as long as permanent income did not increase sharply in that short time period). As mentioned in Section 2.1 (issues 6 and 7), episodes in which increases in wealth are dominated by capital gains make it very difficult to evaluate precautionary savings indirectly and underscore the importance of using subjective measures of desired precautionary wealth. The distribution of this measure from two independent cross sections supports a view that the data are more than just noise. Given the close similarity of the two distributions, we pool the data from SCF95 and SCF98 in the remainder of this paper (all dollar figures are reported in 1995 dollars).

To bring further credibility to our measure and to explain some of the heterogeneity in the whole sample, we examine the distribution of desired precautionary savings across age for each of three education groups: less than 12 years of education, 12-15 years of education, 16 years of education and higher. ${ }^{11}$ The distribution of desired precautionary savings generally mirrors the distribution of wealth across education groups (Figures 3a-c). As reported by many authors (particularly Bernheim and Scholz (1993) and Hubbard, Skinner and Zeldes (1995)), the shape of the wealth distribution varies greatly by education; wealth is particularly low for those with low education. Figure 3a confirms this fact. The distribution of desired precautionary savings is low for the group with less than high school education, and the values remain low

\footnotetext{
${ }^{11}$ In a simple cross-section, we cannot distinguish between age and cohort effects. Thus, when we consider age we do not mean to characterize "age" versus "cohort" effects. To avoid confusion, we use both terms or simply use the term "older sample" to characterize this group in the population.
} 
across age groups. However, values increase overall as we move to groups with higher education (Figures 3b-c). These values are much higher for households headed by people older than 50 .

To address further the heterogeneity exhibited in these plots and to isolate the effects of different types of risk, we split the population into three subgroups. A large fraction of households at the top of the wealth distribution are business owners (Kennickell (2000), Gentry and Hubbard (2004), Hurst and Lusardi (2004)). The risks such people face may often be quite different from those faced by other households. To allow for more detailed investigation of these risks, we consider a sample of business owners only, while we divide the remaining sample between those in working years and those who are retired or close to retirement. The precise definition of the groups is as follows: households that do not own a business and have an employed head aged 25 to 61 (hereafter, "main sample"), households that do not own a business and have a head aged 62 or older (hereafter, "older sample"), and households that own a business in which they have an active management interest (hereafter, "business sample"). ${ }^{12}$ An additional advantage of working with the SCF is that, since it over-samples wealthy households, all these sub-samples, including the business owners, are of relatively large sizes (the number of observations are 4,105, 1,634 and 2,236 for the main sample, the older sample, and the business sample respectively). Note that these three groups face not only substantially different risks, but also different types of constraints and preferences. These are important factors for assessing the empirical importance of precautionary saving and, as mentioned in in Section 2.1 (issues 2-4), it has been hard to account for them empirically. For example, business owners may be less averse

\footnotetext{
${ }^{12}$ Three groups are omitted. First, we exclude households without business holdings and with a head under the age of 62 who was not working at the time of the interview, and households with a head aged less than 25 . These groups were too small and heterogeneous to model with the available data.
} 
to risk than respondents in other groups and may have self-selected into jobs with high risks, while older households may be less likely to face liquidity constraints than young households or business owners.

As the densities in Figure 4 indicate, desired precautionary savings is much larger and values are more dispersed for older sample and the business sample than for the main sample. Particularly for the business sample, the distribution has a long fat right tail. While the median member of the main sample desires to hold $\$ 5,000$ (mean of $\$ 11,000$ ) in terms of precautionary savings, the median household in the older sample wants much more- $\$ 7,600$ (mean of $\$ 29,000)$. The median desired precautionary holding of business owners is the largest at $\$ 10,000$ (mean of $\$ 33,000)$.

To further underscore the differences in the three subsamples, we note that while the main sample accounts for 50 percent of the population, it accounts for only 29 percent of total desired precautionary savings. The older sample accounts for 24 percent of the population, but 41 percent of total desired precautionary savings; the business sample accounts for only 11 percent of the population, but 24 percent of total desired precautionary savings. Together, these two latter groups account for as much as 65 percent of total precautionary savings. Overall, these simple statistics indicate that the treatment of older households and business owners is likely to play a pivotal role in estimating the precautionary saving motive. We return to this point in Section 4 .

\subsection{Evaluating the Importance of Precautionary Savings}

In this section, we report a more formal evaluation of the predictions of the theory and try to assess the importance of the precautionary saving motive. We first examine the size of the 
"buffer-stock" relative to various measures of actual wealth and then show that the measure of desired precautionary savings reported by SCF respondents correlates with risks and other determinants of wealth.

The comparison of desired precautionary savings and actual wealth is complicated by the factors discussed in Section 2.1. First, some households may be away from their equilibrium or target level of wealth because of prior shocks (issue 6). Second, the "correct" concept of wealth to examine is dependent on a variety of preferences and institutional factors governing the liquidity of various assets (issue 1). Because total net worth and financial net worth are the two measures of wealth considered in the majority of the empirical studies on precautionary savings, we begin by comparing these measures with desired precautionary savings.

The amount of desired precautionary savings is frequently larger than financial assets (defined as the sum of net savings and checking deposits, savings bonds, stocks net of margin loans, bonds, mutual funds, and the net cash value of life insurance). We find that financial wealth is less than desired precautionary savings in 48 percent of cases in the main sample, 39 percent of cases among the older sample, and 36 percent for the business sample. When considering total net worth (defined as financial assets with the addition of IRAs, other retirement accounts, housing equity, other real estate, business equity and vehicles minus associated debts, and the net value of miscellaneous assets and debts), the figures change considerably. Net worth is below desired precautionary savings in 17 percent of cases in the main sample, 14 percent in the sample of the older, and 5 percent among business owners.

Given all of the problems noted earlier in measuring wealth, we have also defined an alternative measure of accumulation ("liquidable wealth" hereafter). We have summed financial wealth and given a weight of 0.5 to home equity, other real estate, business equity, vehicles, and 
other miscellaneous assets, and a weight of 0.3 to IRAs and other retirement assets, and only subtracted 6 months of payments on loans except credit cards, and 0.2 of outstanding credit card balances. While these weights are ad-hoc, they represent an attempt to take account of the different liquidity and accessibility of household assets and liabilities. Desired precautionary savings are higher than this alternate measure of wealth for 17 percent of observations in both the main sample and among the older sample and 7 percent among the business sample.

How much of current wealth is the result of precautionary accumulation? The ratio of total desired precautionary savings of all households over total wealth is 8 percent. The ratio increases to close to 20 percent when considering only financial net worth. However, as mentioned before, financial net worth represents a very limited measure of accumulation. Relative to liquidable wealth, the ratio is 12 percent. Thus, although some values of desired precautionary savings are quite large, the precautionary saving motive does not appear overall to account for a very large fraction of observed household wealth. Moreover, because actual wealth may be below its desired equilibrium level, the reported buffer-stock of savings may well represent an upper bound to the size of precautionary wealth at any given time.

How large is the target that households wish to hold compared with permanent income, which is the measure considered in theoretical models? In Figure 5, we consider this distribution of the ratio of desired precautionary savings over permanent income in the full sample and across the sub-groups. ${ }^{13}$ The relative size of the buffer-stock is overall fairly small when we

\footnotetext{
${ }^{13}$ Permanent income is taken to be a measure of "normal" income reported by SCF respondents. This question follows a sequence of questions on actual income. Each respondent was asked whether the total of all components of their income for the preceding year, as summed by the interviewer's computer, was unusually high or low compared to normal. In this case, the respondent was asked for the figure that would be more usual. See Kennickell (1995) for more details.
} 
look at the full sample, but similarly to the measure of savings in levels, the distribution of the ratio has a long fat right tail. The mean value indicates that households desire to hold 64 percent of their normal income as a "buffer-stock," but the median value is 14 percent. However, values vary widely when we examine subgroups. In the main sample, the median desired "buffer-stock" is 10 percent of normal income. Households in the older sample desire to hold much more: The median value is 35 percent of normal income. Households in the business sample also want to hold more than those in the main sample; their median value is 16 percent of normal income.

The evidence is also consistent with another prediction of the "buffer-stock" model. With only very few exceptions, households desire to hold a positive stock of precautionary wealth to insure against shocks. The fact that this stock is typically not very large-it ranges from 15 to 60 percent of permanent income for a large share of the population in working years that do not own a business-is in line with the simulations of Caballero (1991). What our data further show is that precautionary savings become sizable and important for two specific groups: business owners and those older than 62. Other studies had emphasized the large wealth holdings of these groups but without providing a link to the importance of the precautionary saving motive.

Clearly, it is hard to disentangle the size of precautionary accumulation, particularly for these two groups, as wealth can serve more than one purpose. This is why it is important to ask directly for the size of precautionary wealth.

\subsection{A Multivariate Analysis of Desired Precautionary Savings}

The objectives of our empirical analysis are four-fold. First, we aim to explain in more detail the amount of precautionary savings reported by SCF respondents. Second, we examine whether the desired amount of precautionary savings correlates with risk, which is the most 
important prediction of the theory. Third, we aim to understand which types of risk people care about. Fourth, we want to evaluate the findings in the previous literature and assess the importance of the biases mentioned in section 2.1 .

What influences the amount of precautionary savings? As reported in previous sections, there are several factors. First, the main determinant of precautionary accumulation should be risk and, in our work, we do not restrict attention to only one type of risk, but consider several sources of risk (issue 1). Second, preferences are very important in shaping the amount of precautionary savings (issue 2). Finally, the economic environment a family faces, for example liquidity constraints or institutional factors such as the structure of the welfare system, can also affect precautionary accumulation (issues 3,4 , and 5).

Our dependent variable is the $\log$ of desired precautionary savings. Since we have very few zero (and no negative) values, our sample does not suffer from meaningful selection problems. Rather than subtracting the log of permanent income (to express the ratio of desired precautionary wealth to permanent income), we include this variable on the right hand side to allow for the possibility that preferences might be non-homothetic. In order to explain desired precautionary savings, we use a rich set of variables, as reported below.

\section{Income risk and other controls}

As mentioned before, we cannot simply use the variance of income as this measure suffers from many problems. Most importantly, risk-averse workers can self-select into jobs with low income variance. To overcome these issues, we follow the work of other researchers and use the state level rate of unemployment as proxy for risk. ${ }^{14}$ Additionally, to capture income variation which

\footnotetext{
${ }^{14}$ These are the variables used by Lusardi (1997) and Engen and Gruber (2001) in their instrumental variables estimation. These instruments are valid insofar workers do not locate to states according to their degree of
} 
is more individual-specific, we use a dummy for whether the respondent has a good idea of the next year's income. We control for macro shocks (issue 6) by adding to the regression a year dummy and also the absolute deviation of predicted wages from actual wages divided by predicted wages. ${ }^{15}$ We also use dummies for whether the income for the past year was above or below a level the survey respondent considered "normal."

\section{Health risk and other controls}

As in the case of income, it is very hard to measure this variable properly. Furthermore, we cannot use information on whether households have health insurance since that variable is clearly endogenous and can be related to precautionary savings because it proxies for common preferences toward risk (Starr-McCluer(1996)). Studies such as Chandra and Skinner (2002) show there is very high geographical variation in health costs, possibly reflecting differences in utilization and quality of health care. Since even those who have health insurance have to pay some out-of-pocket costs, we proxy for this risk by using the state-specific level of out-of-pocket health costs. Those who live in higher-quality higher-cost states face a higher risk of paying for some of their health problems. This is similar to the approach used to measure income risk. Again, to use a measure which is more individual-specific, we also use information on whether respondents foresee expenses for health care in the next 5-10 years. These expenses are relatively far in the future; thus, they are likely to be uncertain. Since these variables could potentially capture mean costs, we add current health status among our controls.

risk aversion.

\footnotetext{
${ }^{15}$ The predicted wage is estimated using data in the Current Population Survey at the level of three-digit occupation codes. Models were estimated conditioning on age, education, self-employment, sex, and race. Values were predicted for the SCF observations using the estimated parameters.
} 


\section{Longevity risk and other controls}

We proxy for this risk using the coefficient of variation of longevity. This variable is calculated as the ratio of the standard deviation of life expectancy divided by the difference between average life expectancy and the current age.${ }^{16}$ The distribution of life expectancy is simulated for each case using mortality probabilities conditioned on current age, race, and gender. In the regressions, we also account for the reported value of expected longevity and current age.

\section{Business risk and other controls}

The measure of business risk (used for the business sample only) we use is the failure rate of businesses of the same general type and age matched by state. Because the problem of selfselection can be particularly important for this group, the variance of income is not an appropriate variable to use. We also consider whether the head and spouse work in the actively managed business(es) owned by the family to proxy for lack of risk-sharing within the family. Finally, we add to the regressions the number of businesses managed by the family as business risk may be reduced by spanning different types of sectors and activities.

\section{Preferences}

To highlight the importance of preferences and account for the vast heterogeneity in precautionary accumulation, we use a large set of controls. We control for several demographic characteristics, such as age, education, race, marital status, number of children, family size, and wealth dummies. We use wealth dummies (dummies for approximate quintiles of wealth) to account for tastes for saving. Since wealth can be endogenous, we also present results without the wealth dummies. Because it is important to account for behavior toward risk, we use

\footnotetext{
${ }^{16}$ For a couple, we use the maximum value over the two people.
} 
information on respondents' willingness to undertake financial risk to proxy for risk aversion. In addition, we use data on smoking behavior to proxy for impatience. Data on having a saving plan and shopping for returns on saving and investments are used to proxy for attitudes toward saving (Lusardi (2002)). To capture intertemporal substitution and prices, we also consider expectations about interest rates in the next 5 years. Finally, we account for the intention of leaving bequests, as this motive can interact with the precautionary saving motive (wealth accumulated for heirs can also be used to insure against shocks).

\section{Liquidity constraints}

Liquidity constraints are proxied by several variables expressing the possibility of borrowing. We follow the approach of Maki (2000) and Kennickell, Starr-McCluer and Surette (2000) and use the variables reported in their work: a dummy for whether households own bank-type credit cards, the ratio of annualized payments on all types of loans to total normal income, the ratio of credit limit on all credit cards to normal income, the ratio of credit card debt outstanding over the total credit limit on the family's cards, and the interactions of these two latter variables with an indicator for whether families have low income (income lower than $\$ 25,000) .{ }^{17}$ To consider as well the supply of credit, we include the percentage of the local banking market (at the MSA level) held by the four largest depository institutions.

\section{Future expenses and other relevant variables}

We use dummies for other future foreseeable expenses (mainly education and home expenses) in the next 5-10 years to allow for variation in forward looking behavior and future commitments

\footnotetext{
${ }^{17}$ The SCF reports information on whether households have been denied credit in the past or are discouraged borrowers. We do not use these variables in our empirical work since we are interested in future rather than current or past liquidity constraints.
} 
which can also be uncertain. Additionally, we include a dummy for whether pension benefits are considered to be adequate for retirement, since pensions can also insure against risk, particularly longevity risk. In addition, we include a dummy for whether at least one parent is alive. This variable may signal the possibility of receiving inheritances in the future, thus decreasing the need to save.

We control for such an extensive set of variables for several reasons. First, our objective is to describe and explain the data as much as we can, and we do so by exploiting the richness of information offered in the SCF. Second, we aim to show that the proxies we use for risk are not necessarily capturing something other than risk. Third and most importantly, we aim to demonstrate that the data behave according to the predictions of the theory.

Our empirical findings are consistent with the findings of other works on savings. Most importantly, we find that the reported measure of desired precautionary savings correlates with risk(s), even after accounting for a large set of controls. It is also correlated with other determinant of wealth in the expected way. These results are robust and do not depend on the chosen empirical specification. We report the empirical estimates for risk in Table 2; the complete set of estimates is reported in appendix Tables A2-A4. We summarize below the empirical findings for each subsample. ${ }^{18}$

\section{Main sample}

For the main sample, we find that all measures of risk-income, longevity, and health-are significant and correlate positively with desired precautionary savings (Table 2, second column).

\footnotetext{
${ }^{18}$ Estimation was performed using robust regressions. All standard errors were corrected for the multiple imputation of the SCF data (see Kennickell (1998)).
} 
For example, those respondents who live in states with higher unemployment rates save more. Those who have a good idea of next year income desire to accumulate less precautionary saving. However, insofar as there is self-selection of workers into low-risk jobs that is not completely addressed by our proxies for income uncertainty, the estimates are still biased downward (Lusardi $(1997,2000)$ and Fuchs-Schündeln and Schündeln (2003)). Those who face higher health and longevity risk also hold higher amounts of precautionary savings. We do not calculate the economic significance of these estimates, as they may still suffer from the problems discussed in section 2.1. Since we have a measure of precautionary savings already, we can look at this measure directly to assess the size of precautionary wealth and we do not need to rely on the coefficient estimates of risk.

Other variables have the expected sign and significance, confirming that our variable has economic meaning (Table A2). As expected, the amount of desired precautionary savings increases with permanent income. Evaluated at the 1995 population mean for this sample, for an additional \$1,000 of permanent income, households want to hold about an additional \$221 in precautionary wealth. Moreover, precautionary accumulation increases sharply with education, even after accounting for wealth dummies. Thus, differences in precautionary wealth across education groups documented in Figures 3a-c and in other studies (Hubbard, Skinner and Zeldes (1995), Lusardi $(1998,2000))$ are still large even after accounting for many determinants of wealth.

Moreover, we find that if pensions are adequate, precautionary accumulation is substantially lower (about 4 to 5 percent lower). Planning is also important. Respondents who have a saving plan report higher precautionary savings and so do those that search for the best conditions on investment; work by Lusardi (2002) and Ameriks, Caplin and Leahy (2003) shows 
that planning is a major determinant of wealth accumulation. Not only preferences, but also the economic environment matters for precautionary savings. Respondents who are more likely to face constraints (they report high loan payments or live in areas with a low concentration of large banks) accumulate higher precautionary savings.

While most of the variables used in the empirical work move in the expected way, there is still much unexplained variation. Again, this suggests that it is going to be difficult to find evidence of precautionary savings in micro data by estimating the function reported in Section 2.1. First, there is a lot of heterogeneity in household behavior toward precautionary savings. Second, people may care about many risks. Assessing the importance of the precautionary motive by looking at only one source of risk can give a limited and perhaps misleading assessment of the importance of the precautionary saving motive.

\section{Older sample}

It is important to focus attention on this group which accounts for such a disproportionate share of precautionary savings. Not many studies have examined this group in isolation and we know relatively little about the importance of precautionary savings among older people. However, this group is often included in the samples used to estimate the precautionary saving motive.

It is reassuring to note that, for this group, unemployment risk and income risk in general are not significant (Table 2, third column). Many of these households are retired or on the verge of retirement and, generally, income risk should not play an important role in explaining their precautionary accumulation. As expected, two other risks are relevant: health and longevity risk. Both variables are statistically significant. 
As for the main sample, precautionary savings for older households increase with both permanent income and education (Table A3). As before, differences are sizable across education groups and precautionary savings are high particularly among those with a college degree or more education. Other variables show the expected results. For example, the liquidity constraint variables are overall not statistically significant. Older people/cohorts who have a bequest motive accumulate more precautionary savings. As we discussed earlier, households who have a bequest motive may hold on to their wealth until the end of life to potentially offset negative shocks. There is however, more variation in desired precautionary savings among older households/cohorts than we can measure with our simple proxies. While the two risks mentioned above play a role, there are potentially more sources of risk that the older famlies care about and would like to insure against. Modeling the saving behavior of this group is, therefore, likely to be quite complex and require more detailed information on the risk factors facing older families.

\section{Business sample}

No one has studied this group in detail to assess the importance of the precautionary saving motive, but according to our descriptive results presented earlier in this paper, this group is very important for understanding wealth accumulation. To study business owners effectively, we added several variables related to business risk. As mentioned before, we account for whether both spouses work in the business and, thus, for lack of risk sharing within the household. We also account for the number of businesses actively managed by the respondent or spouse (Table 2 , fourth column). We also account for business size and type to account for the large heterogeneity in business ownerships and whether the head or spouse has a MBA (Tables A4). 
Overall, it is very hard to decompose the variation in desired precautionary holdings for business owners with the available data; even basic demographic variables are not statistically significant. The risk measures, such as unemployment and income risk, are significant and so are some proxies for health risk, but, for example, the business failure risk variables are not significant (Table 2). A variable that is strongly significant is the number of businesses owned by the family and actively managed. Contrary to initial expectations, the higher the number of businesses, the higher the precautionary savings. This perhaps is due to the fact that there is little risk diversification in running more than one business; often owners of multiple businesses have businesses in closely related areas.

Liquidity constraints matter for business owners and, consistent with theoretical predictions, those that are more likely to face constraints hold higher amounts of precautionary savings. Like the main sample, business owners that have adequate pensions report lower precautionary savings.

This group is very important but also very difficult to study, largely because it is seemingly so heterogeneous. Previous works that concentrate on earnings risk can do only a crude job of capturing the importance of the precautionary saving motive when business owners are included in the sample. On the other hand, they play a pivotal role in empirical work since they hold large amounts of wealth.

\subsection{Another Look at the Quantitative Importance of Precautionary Savings}

In the previous section, we have shown that our measure of desired precautionary savings is dependent on risk(s) and other expected factors. As mentioned in Section 2.1, it has been difficult to measure risk other than income risk, often due to lack of data. Other studies that 
have considered more than one source of risk have not clearly indicated the importance of precautionary savings due, for example, to health or other shocks, perhaps with the exception of Carroll and Samwick (1997). To provide insights on this matter, we exploit the information on the motives to save reported in the SCF (the list of responses is reported in appendix Table A1). The question about saving motives precedes that about desired precautionary savings (with a number of questions about preferences and attitudes about saving in between). From the reported saving motives, we are able to isolate four categories of precautionary savings related to different types of risks:

1) Emergencies, "rainy days," other unexpected needs, for "security" and independence;

2) Reserves in case of unemployment;

3) In case of illness, medical/dental expenses;

4) To have cash available on hand/liquidity; wise/prudent things to do.

As a simple way of inferring the quantitive importance of different types of risk, we simply regress the ratio of desired precautionary savings to permanent income on these four dummies using robust regressions (along with dummy variables to control for wealth). What emerges from these simple regressions is that, relative to other risks, it is health risk that gives rise to the largest amounts of precautionary savings overall (Table 3). This finding is consistent with what was reported earlier, in particular for the older sample. On the other hand, earnings (unemployment) risk, which is the risk that has been considered in the majority of the papers on precautionary savings, does not account for high amounts of precautionary accumulation in the total sample but, as expected, is more relevant in the main sample. Only a very small number of respondents in the older and the business owner sample reported this motive as either their first 
or second most important reason to save. ${ }^{19}$ Estimates are consistent with the recent work of Carroll, Dynan and Krane (2003), which also finds small amounts of precautionary wealth to insure against unemployment risk. Overall, what emerges again from these simple regressions is that we need to move beyond earnings risk when modeling precautionary accumulation, in particular when evaluating the quantitative importance of the precautionary saving motive in comprehensive surveys that include all types of households.

\section{Discussion}

According to our findings a precautionary saving motive exists and affects the behavior of households. However, the precautionary saving motive does not give rise to high amounts of wealth, at least for the group of households who are in working years and do not own a business. Simply stated, our data show that precautionary savings may account for as much as $8 \%$ of total accumulation in the US. These estimates are similar to the upper range of values obtained in studies of precautionary savings using subjective measures of risk. Our findings further indicate that we need to move beyond earnings risk when modeling precautionary accumulation. Older households play a very important role in explaining precautionary savings and for them, it is very important to model health and longevity risks as well as other sources of risk (for example “consumption" risk and other such emergencies). Health risk may also lead to sizable amounts of precautionary accumulation. Thus, models that incorporate more than one source of risk are likely to be better suited to modeling the behavior of households, particularly in samples that do not concentrate on the young only.

\footnotetext{
${ }^{19}$ However, it may be that some part of the health saving motive indirectly signals saving for lost wages during times of ill health.
} 
There is also another group that deserves close attention: business owners. Our work shows that it is very hard to characterize their behavior well. There are several problems in measuring properly the risk that these households face (not only income and business failure risk but also, for example, interest rate risk). Most importantly, these households may self-select into self-employment because of their risk tolerance or their perceptions of risk. Moreover, these households are less likely to have pensions and to retire at age 62 or 65 (Hurst and Lusardi (2004)). Our estimates suggest that it will be fruitful to study them in isolation. Alternatively, models that include business owners should at least attempt to model more adequately their differences with respect to other households.

Our results provide insights into previous empirical findings using the regressions that were discussed in Section 2. For example, we can better understand the findings of Kazarosian (1999) and Lusardi $(1998,2000)$, which examine older workers. They find that a precautionary saving motive exists even for older households and, as this study also shows, older households display a strong precautionary saving motive. We can also explain the finding of the well-cited paper by Carroll and Samwick (1998), which shows that precautionary savings tend to become more, rather than less, important with the addition of older respondents (older than 50). Our findings can also explain another and potentially puzzling result of Carroll and Samwick (1998). When farmers and self-employed are excluded from their sample, not only do the coefficient estimates on income risk drop by 50 to 60 percent, but they are also no longer statistically significant. As reported above, precautionary wealth is relatively small in the main sample, but it becomes large for business owners. This group surely plays a pivotal role in the estimates of precautionary savings. 
Our results also provide insights into another important and puzzling finding: the lack of annuitization among the older households. As many authors have shown, many retirees do not annuitize their wealth. Furthermore, when given the option, many retirees choose lump-sum payments rather than annuities for their retirement income (see Ameriks (2003) and the references therein). If retirees face risks other than simply longevity, this behavior is reasonable. Our data provide evidence that respondents in the older sample care about many sources of risk. Similarly, it can explain why households do not use reverse mortgages (Venti and Wise (1991)). If older households face the risk of incurring high expenses, for example large health expenses, they may be reluctant to downsize or annuitize the value of their house. This result is consistent with the work of Skinner (1996), which also emphasizes the importance of the precautionary saving motive among older households.

Our findings are also in line with the work by Hubbard, Skinner and Zeldes (1995), which shows that low-income and low-education families have little precautionary savings. As the authors argue, this may be due to the existence of welfare programs. While households at the bottom of the wealth distribution may face high risk, this risk interacts with means-tested welfare programs in a nonlinear way. Finally, our findings are consistent with the evidence regarding motives to save. As reported in many data sets, the precautionary saving motive is consistently the most important motive indicated by respondents, and, as reported by Alessie, Lusardi and Aldershof (1997), Kennickell (1995) and Samwick (1998), it remains strong among older cohorts. However, as reported by Horioka, Yokota and Miyaji (1994), households indicating a precautionary saving motive do not hold large amounts of wealth.

How important is the precautionary saving motive? Consistent with the findings of other studies, our work shows that a precautionary motive exists and affects virtually every household. 
Thus, models of savings that rely on certainty equivalence, preferences, or economic environments that do not generate precautionary savings will not be able to characterize well the behavior of US households. What this study further suggests is that this motive is very heterogenous across the population, much more so than what has been found in previous work. This difference may be because only a limited number of sources of risk have previously been considered in the empirical literature and/or because it is hard to capture well empirically all the complexities of precautionary accumulation, as discussed in Section 2. Income risk, in particular, is likely to give rise to little precautionary accumulation, but other risks, such as health and business risk, can lead to large amounts of precautionary accumulation.

For a large part of the younger population, our findings are consistent with studies using subjective measures of risk in that the precautionary saving motive does not give rise to a lot of wealth (Guiso, Jappelli and Terlizzese (1992), Lusardi (1998, 2000), Arrondel (2002)). Thus, we believe that some of the initial large estimates of precautionary savings coming out of simulations for the aggregate economy do not characterize well the behavior of the average or the median household in the economy. Similar findings are reported in the recent theoretical work and simulation results by Irvine and Wang (2001, page 234), which also state that "the overall wealth stock in the economy is less influenced by income uncertainty than the existing theoretical literature suggests." Similarly, Laitner (2004) finds that, for plausible calibrations, precautionary saving only adds $5-6 \%$ to aggregate wealth. However, our findings are also consistent with some of the simulations of Carroll (1992) and Cagetti (2000). Households in these models display low degrees of patience or low risk aversion. This leads to low amounts of accumulation, particularly for low educated and young households. Although consistent with those predictions, our findings 
further suggest that there is much more heterogeneity in the precautionary saving motive than usually generated by these stylized models.

One of the novelties of our paper with respect to previous work is that we can identify two groups in the population for which precautionary savings are really important: older households and business owners. Consideration of business owners, a group that can account for a large share of aggregate wealth, suggests that not just income risk, but also other risks should be taken into account. The same holds for older households. In addition, it is likely that differences in preferences and economic circumstances in these groups give rise to much of the observed heterogeneity. Our subjective measure of precautionary savings can at least provide some bounds to evaluate the importance of this motive among these distinct groups of households. Further research on precautionary savings should give more attention to the behavior of these two groups in the population.

\section{Concluding Remarks}

The estimation of the precautionary saving motive is a very complex task. There exist many pitfalls and difficulties in assessing the empirical importance of this motive. One of the major problems is how to measure accurately the amount of reserves people use to shield themselves against risk. The commonly used measures of wealth have many problems, and much more attention should be devoted to this important issue.

Our approach deviates from previous works and relies on a subjective measure of precautionary savings provided in the SCF. This survey, by oversampling the wealthy, provides a reasonably accurate account of the range of household wealth holdings. Beginning in 1995, the SCF also provides a measure of desired precautionary savings, further enriching the information 
currently available to study household behavior toward savings. We provide an extensive evaluation of this measure. The underlying question was subjected to careful pre-testing as well as post-survey evaluation. We show that the measure is consistent across time-periods; two independent cross-sections in 1995 and 1998 give very much the same results. The decomposition across groups shows that the features of the data accord with the theory. In particular, the shape of the distribution of desired precautionary savings mimics that of wealth, but at a much lower level than wealth. Finally, desired precautionary savings correlates with risk, permanent income, liquidity constraints, and household preferences.

Our findings shed new light on the importance of precautionary savings. The precautionary saving motive continues to be strong even among older households/cohorts. Thus, we need to move beyond earnings risk when studying the importance of precautionary accumulation. Moreover, the precautionary saving motive is very important for business owners and, for this group as well, we need a more careful modeling of sources of risk. Given that older households and business owners alone account for 65 percent of total precautionary accumulation, further research on this topic should focus on these two groups of the population. Because the heterogeneity seen in our data is large, it may be particularly important to enrich the description of the economic environment, including accounting for imperfections in the financial and insurance markets and the institutions that are already in place to insure against risk (e.g., welfare programs, sources of support from family and friends).

The measure of desired precautionary wealth available in the SCF can substantially enhance empirical work. For example, researchers interested in accounting for a measure of precautionary accumulation can use this information rather than relying on traditional measures of wealth. Furthermore, these data can be used to account for household-specific behavior toward 
risk. There is little information in existing data sets on risk aversion, prudence, or the amount and type of risks that households face; in principle, the subjective measure of precautionary wealth in the SCF encompasses all such information. Thus, studies of portfolio choice, entrepreneurship, and the labor market can benefit much from the availability of this information. These data can also help yield better understanding of other questions concerning household saving behavior, such as whether and how fast older households should decumulate wealth after retirement and what are the most important motives for saving. 


\section{References}

Alan, Sule (2004), "Precautionary Wealth and Portfolio Allocation: Evidence from Canadian Microdata," mimeo, York University, Canada.

Ameriks, John (2003), "How Do Retirees Go from Stocks to Flow?," mimeo, TIAA-CREF Institute.

Ameriks, John, Andrew Caplin and John Leahy (2003), "Wealth Accumulation and the Propensity to Plan," Quarterly Journal of Economics, 68, 1007-1047.

Alessie, Rob, Annamaria Lusardi and Trea Aldershof (1997), "Income and Wealth over the Life Cycle: Evidence from Panel Data," Review of Income and Wealth, 43, 1-32.

Arrondel, Luc (2002), "Risk Management and Wealth Accumulation Behavior in France," Economics Letters, 74, 187-194.

Attanasio, Orazio James Bank, Costas Meghir and Guglielmo Weber (1999), "Humps and Bumps in Lifetime Consumption," Journal of Business and Economic Statistics.

Barsky, Robert, Miles Kimball, Thomas Juster and Matthew Shapiro (1997), "Preference Parameters and Behavioral Heterogeneity: An Experimental Approach in the Health and Retirement Survey," Quarterly Journal of Economics, 62, 537-579.

Bernheim, Douglas and John Karl Scholz (1993), "Private Saving and Public Policy, " in James Poterba (ed.), Tax Policy and the Economy, MIT Press, 73-110.

Börsch-Supan, Axel and Lothar Essig (2003), "Household Saving in Germany: Results from the First SAVE Study,” NBER Working Paper n. 9902.

Browning, Martin and Annamaria Lusardi (1996), "Household Saving: Micro Theories and Micro Facts," Journal of Economic Literature, 34, 1797-1855.

Caballero, Ricardo (1991), "Earning Uncertainty and Aggregate Wealth Accumulation," American Economic Review, 81, 859-871.

Caballero, Ricardo (1990), “Consumption Puzzles and Precautionary Savings," Journal of Monetary Economics, 25, 113-136.

Cagetti, Marco (2000), "Wealth Accumulation Over the Life Cycle and Precautionary Savings," mimeo, University of Virginia.

Carroll, Christopher (1992), "The Buffer-Stock Theory of saving: Some Macroeconomic Evidence," Brookings Papers on Economic Activity, 2, 61-156. 
Carroll, Christopher (1996), “Buffer Stock Saving: Some Theory,” mimeo, Johns Hopkins University.

Carroll, Christopher (1997), "Buffer Stock Saving and the Life Cycle/Permanent Income Hypothesis,"Quarterly Journal of Economics, 112, 1-55.

Carroll, Christopher and Andrew Samwick (1998), “ How Important is Precautionary Saving?" Review of Economics and Statistics, 80, 410-419.

Carroll, Christopher and Andrew Samwick (1997), "The Nature of Precautionary Wealth,” Journal of Monetary Economics, 40, 41-71.

Carroll, Christopher, Karen Dynan and Spencer Krane (2003), "Unemployment Risk and Precautionary Wealth: Evidence from Households' Balance Sheets," Review of Economics and Statistics, 85, 586-604.

Chandra, Amitabh and Jonathan Skinner (2002), "Geography and Health Disparities," National Academies of Sciences, Workshops on Ethnic Disparities in Aging Health, Washington, D.C. .

Dardanoni, Valentino (1991), "Precautionary Savings under Income Uncertainty: A CrossSectional Analysis," Applied Economics, 23, 153-160.

Davies James (1981), “Uncertain Lifetimes, Consumption and Dissaving in Retirement,” Journal of Political Economy, 89, 561-578.

Deaton, Angus (1991), “Saving and Liquidity Constraints,” Econometrica, 59, 1221-1248.

Deaton, Angus (1992), Understanding Consumption, Oxford: Oxford University Press.

Drèze, Jacques and Franco Modigliani (1972), “Consumption Under Uncertainty,” Journal of Economic Theory, 5, 308-35.

Dynan, Karen (199,), “How Prudent Are Consumers?, Journal of Political Economy, 101, 11041113.

Engen, Eric and Jonathan Gruber (2001), "Unemployment Insurance and Precautionary saving," Journal of Monetary Economics, 47, 545-579.

Fuchs-Schündeln Nicola and Matthias Schündeln (2003), "Precautionary Savings and SelfSelection - Evidence from the German Reunification 'Experiment,"” mimeo, Yale University.

Gentry, William and Glenn Hubbard (2004), “Entrepreneurship and Household Saving,”Advances in Economic Analysis \& Policy, 4(1), Article 8. 
Gourinchas, Pierre Olivier and Jonathan Parker (2002), "Consumption Over the Life Cycle," Econometrica, 70, 47-89.

Guiso, Luigi, Tullio Jappelli and Daniele Terlizzese (1996), "Income Risk, Borrowing Constraints and Portfolio Choice," American Economic Review, 86, 158-172.

Guiso, Luigi, Tullio Jappelli and Daniele Terlizzese (1992), "Earning Uncertainty and Precautionary Saving," Journal of Monetary Economics, 30, 307-338.

Haliassos, Michael and Carol Bertaut (1995), "Why Do So Few Hold Stocks?," Economic Journal, $105,1110-1129$.

Heaton, John and Deborah Lucas (2000), "Portfolio Choice and Asset Prices: The Importance of Entrepreneurial Risk," Journal of Finance, 55, 1163-1198.

Hrung, Warren (2000), "Is Retirement an Important Motive for Saving? An Investigation of Buffer-Stock Savings using Tax Panel Data," mimeo, US Department of Treasury.

Hochguertel, Stefan (2003), "Precautionary Motives and Portfolio Choice," Journal of Applied Econometrics, 18, 61-77.

Horioka, Charles, Naoto Yokota, and Toshiyuki Miyaji (1994), “Why Do People Save? An Analysis of Motives for Household Saving in Japan," Discussion Paper n. 350, Institute of Social and Economic Research, Osaka University, Japan.

Hubbard, Glenn, Jonathan Skinner and Stephen Zeldes (1995), "Precautionary Saving and Social Insurance," Journal of Political Economy, 103, 360-399.

Hurst, Erik and Annamaria Lusardi (2004), "Liquidity Constraints, Household Wealth and Entrepreneurship,” Journal of Political Economy, 112, 319-347.

Irvine, Ian and Susheng Wang (2001), "Saving Behavior and Wealth Accumulation in a Pure Lifecycle Model with Income Uncertainty,” European Economic Review, 45, 233-258.

Juster, Thomas James Smith and Frank Stafford (1999), "The Measurement and Structure of Household Wealth, Labour Economics, 6, 253-275.

Kazarosian, Mark (1997), "Precautionary Saving - A Panel Study," Review of Economics and Statistics, 79, 241-247.

Kennickell, Arthur (2000) "An Examination of Changes in the Distribution of Wealth from 1989 to 1998: Evidence from the Survey of Consumer Finances," Jerome Levy Economics Institute Working Paper 307. 
Kennickell, Arthur (1998), "Multiple Imputation in the Survey of Consumer Finances," Proceedings of the Section on Business and Economic Statistics, 1998 Annual Meetings of the American Statistical Association, Dallas, Texas

Kennickell, Arthur (1995), "Saving and Permanent Income: Evidence from the 1992 SCF," mimeo, Board of Governors.

Kennickell, Arthur, Martha Starr-McCluer and Brian J. Surette (2000), "Recent Changes in U.S. Family Finances: Results from the 1998 Survey of Consumer Finances, Federal Reserve Bulletin, $1-29$.

Kennickell, Arthur, Martha Starr-McCluer, and Annika E. Sundén (1997), "Family Finances in the U.S.: Recent Evidence from the Survey of Consumer Finances," Federal Reserve Bulletin, 1-24.

Kennickell, Arthur and Louise Woodburn (1999), "Consistent Weight Design for the 1989, 1992, and 1995 SCFs, and the Distribution of Wealth," Review of Income and Wealth, 45, 193-215.

Kimball, Miles (1990), "Precautionary Saving in the Small and in the Large," Econometrica, 58, 53-73.

Laitner, John (2004), "Precautionary Saving Over the Lifecycle," Michigan Retirement Research Center Working Paper n. 83.

Leung, Siu Fai (1994), "Uncertain Lifetime, the Theory of the Consumer, and the Life Cycle Hypothesis, Econometrica, 62, 1233-1239.

Lusardi, Annamaria (2002), "Explaining Why So Many Households Do Not Save,” mimeo, Dartmouth College.

Lusardi, Annamaria (2000), "Precautionary Saving and the Accumulation of Wealth," mimeo, Dartmouth College.

Lusardi, Annamaria (1998), "On the Importance of the Precautionary Saving Motive," American Economic Review Papers and Proceedings, 88, 449-453.

Lusardi, Annamaria (1997), "Precautionary Saving and Subjective Earnings Variance, “" Economics Letters, 57, 319-326.

Maki, Dean (2000), "The Growth of Consumer Credit and the Household Debt Service Burden," mimeo, Board of Governors of the Federal Reserve System.

Palumbo, Michael (1999), "Uncertain Medical Expenses and Precautionary Saving Near the End of the Life Cycle," Review of Economic Studies, 66, 395-421.

Poterba, James (2003), "Valuing Assets in Retirement Saving Accounts," mimeo, MIT. 
Poterba, James, Steven Venti, and David Wise (1994), "Targeted Retirement Saving and the Net Worth of Elderly Americans," American Economic Review Papers and Proceedings, 84,180-85.

Skinner, Jonathan (1996), "Is Housing Wealth a Sideshow?" in D. Wise (ed.), Papers in the Economics of Aging, Chicago: Chicago University Press.

Skinner, Jonathan (1988), "Risky Income, Life Cycle Consumption and Precautionary Saving," Journal of Monetary Economics, 22, 237-255.

Starr-McCluer, Martha (1996), "Health Insurance and Precautionary Savings, American Economic Review, 86, 285-295.

Venti Steven and David Wise (1991), “Aging and the Income Value of Housing Wealth,” Journal of Public Economics, 44, 371-397. 
Table 1: Empirical Issues in Estimating the Importance of Precautionary Savings

\begin{tabular}{|c|c|c|c|c|c|}
\hline \# & Issues & $\begin{array}{c}\text { Empirical } \\
\text { Implementation }\end{array}$ & $\begin{array}{l}\text { Relevant papers that } \\
\text { face or address issue }\end{array}$ & Problems & $\begin{array}{l}\text { Direction } \\
\text { of bias }\end{array}$ \\
\hline 1 & $\begin{array}{l}\text { Measurement } \\
\text { of wealth }\end{array}$ & $\begin{array}{l}\text { Use financial } \\
\text { wealth }\end{array}$ & $\begin{array}{l}\text { Hrung (2000) } \\
\text { Engen et al (2001) } \\
\text { Carroll et al (1998) } \\
\text { Alan (2004) }\end{array}$ & $\begin{array}{l}\text { Very limited } \\
\text { measure of } \\
\text { accumulation }\end{array}$ & $\downarrow$ \\
\hline 1 & $\begin{array}{l}\text { Measurement } \\
\text { of risk }\end{array}$ & $\begin{array}{l}\text { Use subjective } \\
\text { measures of } \\
\text { income variance }\end{array}$ & $\begin{array}{l}\text { Guiso et al. (1992) } \\
\text { Lusardi (1998) } \\
\text { Arrondel (2002) }\end{array}$ & $\begin{array}{l}\text { Income variance is } \\
\text { very low }\end{array}$ & $\downarrow$ \\
\hline 2 & $\begin{array}{l}\text { Preferences: } \\
\text { Risk Aversion }\end{array}$ & $\begin{array}{l}\text { Use occupation } \\
\text { dummies as proxy } \\
\text { for risk }\end{array}$ & $\begin{array}{l}\text { Skinner (1988) } \\
\text { Lusardi (1997) } \\
\text { Fuchs-Schundeln et } \\
\text { al. (2003) }\end{array}$ & $\begin{array}{l}\text { Risk-averse } \\
\text { workers can self- } \\
\text { select into low risk } \\
\text { occupations }\end{array}$ & $\downarrow$ \\
\hline 3 & $\begin{array}{l}\text { Liquidity } \\
\text { constraints }\end{array}$ & $\begin{array}{l}\text { Use proxies for } \\
\text { constraints }\end{array}$ & Guiso et al. (1996) & $\begin{array}{l}\text { Mostly un- } \\
\text { observable }\end{array}$ & $\begin{array}{l}\text { Imprecise } \\
\text { estimates }\end{array}$ \\
\hline 4 & $\begin{array}{l}\text { Other forms } \\
\text { of insurance }\end{array}$ & $\begin{array}{l}\text { Use data on } \\
\text { sources of help } \\
\text { and support }\end{array}$ & $\begin{array}{l}\text { Hubbard et al. (1995) } \\
\text { Lusardi (2000) }\end{array}$ & $\begin{array}{l}\text { Mostly un- } \\
\text { observable }\end{array}$ & $\begin{array}{l}\text { Imprecise } \\
\text { estimates }\end{array}$ \\
\hline 5 & $\begin{array}{l}\text { Functional } \\
\text { form }\end{array}$ & Use logs & Carroll et al (1998) & $\begin{array}{l}\text { Heavily selected } \\
\text { sample }\end{array}$ & 4 \\
\hline 6 & $\begin{array}{l}\text { Macro and } \\
\text { past shocks }\end{array}$ & $\begin{array}{l}\text { Use proxies for } \\
\text { past shocks }\end{array}$ & $\begin{array}{l}\text { Lusardi }(1998,2000) \\
\text { Carroll, Dynan and } \\
\text { Krane (2003) }\end{array}$ & $\begin{array}{l}\text { Both wealth and } \\
\text { income risk are } \\
\text { sensitive to the } \\
\text { business cycle }\end{array}$ & $\downarrow$ \\
\hline 7 & $\begin{array}{l}\text { Portfolio } \\
\text { choice }\end{array}$ & $\begin{array}{l}\text { Include stocks in } \\
\text { the measure of } \\
\text { wealth }\end{array}$ & Most papers & $\begin{array}{l}\text { Those facing high } \\
\text { income risk should } \\
\text { invest less in } \\
\text { stocks }\end{array}$ & $\downarrow$ \\
\hline 8 & $\begin{array}{l}\text { Other motives } \\
\text { to save }\end{array}$ & $\begin{array}{l}\text { Entrepreneurs and } \\
\text { older households } \\
\text { are included in the } \\
\text { sample }\end{array}$ & Most papers & $\begin{array}{l}\text { Interaction of } \\
\text { enterprise \& } \\
\text { bequest with } \\
\text { precautionary mot. }\end{array}$ & $\hat{\uparrow}$ \\
\hline
\end{tabular}

Note: This table summarizes the empirical issues in estimating precautionary savings discussed in section 2.1 in the text. 
Table 2: Summary of Key Regression Estimates, by Sample Group.

\begin{tabular}{|c|c|c|c|}
\hline & Main sample & Older sample & Business Sample \\
\hline Variables: risk and permanent income & Estimates (s.e.) & Estimates (s.e.) & Estimates (s.e.) \\
\hline State unemployment rate & $0.042(0.020)^{* *}$ & $0.011(0.042)$ & $0.053(0.029)^{* *}$ \\
\hline $\begin{array}{l}\text { Respondent has good idea of next year's } \\
\text { income }\end{array}$ & $-0.124(0.044)^{* * *}$ & $-0.024(0.096)$ & $-0.032(0.065)$ \\
\hline State out-of-pocket health costs & $-0.000(0.000)$ & $0.000(0.000)$ & $-0.000(0.000)$ \\
\hline Future health expenditure & $0.230(0.057)^{* * *}$ & $0.369(0.095)^{* * *}$ & $0.203(0.093)^{* *}$ \\
\hline Longevity risk & $3.043(0.759)^{* * *}$ & $5.409(1.660)^{* * *}$ & $1.140(1.856)$ \\
\hline $\begin{array}{l}\text { State failure rate of businesses of same } \\
\text { type \& age }\end{array}$ & - & - & $0.011(0.018)$ \\
\hline $\begin{array}{l}\text { Head works in actively managed firm } \\
\text { owned by family }\end{array}$ & - & - & $-0.035(0.113)$ \\
\hline $\begin{array}{l}\text { Spouse works in actively managed firm } \\
\text { owned by family }\end{array}$ & - & - & $0.003(0.073)$ \\
\hline $\begin{array}{l}\text { Family own } 2 \text { businesses they actively } \\
\text { manage }\end{array}$ & - & - & $-0.042(0.082)$ \\
\hline $\begin{array}{l}\text { Family own more than } 2 \text { businesses they } \\
\text { actively managed }\end{array}$ & - & - & $0.304(0.099)^{* * *}$ \\
\hline Log of permanent income & $0.319(0.031)^{* * *}$ & $0.137(0.050)^{* * *}$ & $0.360(0.034)^{* * *}$ \\
\hline $\begin{array}{l}\text { Preferences, liquidity constraints, future } \\
\text { expenses, and other controls }\end{array}$ & yes & yes & yes \\
\hline Wealth dummies & yes & yes & yes \\
\hline \# of observations & 4105 & 1634 & 2236 \\
\hline
\end{tabular}

Note: This table summarizes the estimates of the regressions of desired precautionary savings (in logs) on the variables measuring risk (income, health, and business risk) and permanent income. The full set of estimates is reported in Tables A2-A4. Column 2 reports the estimates in the main sample, while columns 3 and 4 report the estimates in the older sample and the business sample. “*”, “**, “***” indicate significance at the $10 \%, 5 \%$ and $1 \%$ level, respectively. 
Table 3: Precautionary Savings and Motives to Save

\begin{tabular}{|l|l|l|l|l|}
\hline Variables & Full sample & Main sample & Older sample & Business sample \\
\hline Constant & $\begin{array}{l}0.123^{* * *} \\
(0.005)\end{array}$ & $\begin{array}{l}0.097 * * * \\
(0.003)\end{array}$ & $\begin{array}{l}0.266^{* * *} \\
(0.026)\end{array}$ & $\begin{array}{l}0.159^{* * *} \\
(0.022)\end{array}$ \\
\hline Emergencies & $\begin{array}{l}0.014^{* * *} \\
(0.004)\end{array}$ & $\begin{array}{l}0.010^{* * *} \\
(0.004)\end{array}$ & $\begin{array}{l}0.026 \\
(0.026)\end{array}$ & $\begin{array}{l}0.016^{*} \\
(0.011)\end{array}$ \\
\hline Unemployment & $\begin{array}{l}0.018^{*} \\
(0.014)\end{array}$ & $\begin{array}{l}0.033^{* * *} \\
(0.011)\end{array}$ & $\begin{array}{l}-0.118 \\
(0.120)\end{array}$ & $\begin{array}{l}0.020 \\
(0.038)\end{array}$ \\
\hline Health expenses & $\begin{array}{l}0.044^{* *} \\
(0.010)\end{array}$ & $\begin{array}{l}0.018^{* *} \\
(0.009)\end{array}$ & $\begin{array}{l}0.077 * * \\
(0.033)\end{array}$ & $\begin{array}{l}0.001 \\
(0.023)\end{array}$ \\
\hline $\begin{array}{l}\text { Liquidity, wise/prudent } \\
\text { thing to do }\end{array}$ & $\begin{array}{l}0.019 * * \\
(0.011)\end{array}$ & $\begin{array}{l}0.013 \\
(0.012)\end{array}$ & $\begin{array}{l}0.000 \\
(0.046)\end{array}$ & $\begin{array}{l}0.027 \\
(0.024)\end{array}$ \\
\hline Wealth dummies & yes & yes & yes & yes \\
\hline
\end{tabular}

Note: This table reports the estimates from a regression of the ratio of desired precautionary savings over permanent income on the dummies for the motives to save reported in the first column. All regressions include a set of wealth dummies to account for household preferences. “*”, “**, “***” indicate significance at the $10 \%, 5 \%$ and $1 \%$ level, respectively. 


\section{Data Appendix}

The data used in this paper derive from the 1995 and 1998 cross-sections of the Survey of Consumer Finances (SCF). The SCF is sponsored by the Board of Governors of the Federal Reserve System, and the data for the 1995 and 1998 surveys were collected by NORC, a national organization for social science and survey research at the University of Chicago. The field period ranged from approximately June through December of the survey years. All asset and liability variables used in this paper are valued as of the time of the interview. All dollar values from the 1998 SCF have been adjusted to 1995 dollars using the Consumer Price Index (CPI).

In each of the two years of the SCF we use, there are about 4,300 participants. The original sample comprises two random sub-samples. The first is an area-probability sample, which accounts for about two-thirds of the participants. This part of the sample provides broad national coverage of the population. The second part contains an over-sample of wealthy households. Non-response to the survey is a substantial problem which is addressed through the weighting design (Kennickell and Woodburn, 1999). For individual questions, non-response, or partial response in the form of range information, is also a problem. The survey deals with this type of non-response through multiple imputation (Kennickell, 1998), a technique that allows one to account for the variability associated with non-response in model estimation. The standard errors of all models presented in this paper are corrected for the imputation of the originally missing data. See Kennickell, Starr-McCluer, and Sundén (1997), and Kennickell, Starr-McCluer and Surette (2000) for more information on the SCF in 1995 and 1998. 
Table A.1: Motives to Save in the 1995 SCF

\begin{tabular}{|c|c|}
\hline Motives to save & $\begin{array}{l}\text { Percentages in the } \\
\text { total sample }\end{array}$ \\
\hline $\begin{array}{l}\text { Emergencies, "rainy days," other unexpected needs, for "security" and } \\
\text { independence }\end{array}$ & 36.2 \\
\hline In case of illness, medical/dental expenses & 6.3 \\
\hline Reserves in case of unemployment & 2.4 \\
\hline Liquidity, to have cash available/on hand, wise/prudent thing to do & 2.5 \\
\hline Retirement/old age & 32.4 \\
\hline "To get ahead", for the future, to advance standard of living & 6.2 \\
\hline Children or grandchildren's education, own or spouse education & 18.2 \\
\hline For the children/family, "to help the kids out" & 5.4 \\
\hline $\begin{array}{l}\text { Buying own house, cottage, second house, home improvements/repairs, } \\
\text { to meet contractual commitments to pay off house }\end{array}$ & 11.5 \\
\hline $\begin{array}{l}\text { Buying a car, boat or other vehicle, buy durable household goods, to travel, take } \\
\text { vacations }\end{array}$ & 17.6 \\
\hline Buying (investing in) own business/farm, equipment for business/farm & 1.8 \\
\hline No reason, money "left over" & 0.6 \\
\hline Don't/can't save, "have no money" & 6.8 \\
\hline Other motives & 7.4 \\
\hline
\end{tabular}

Note: This table reports the frequencies of the responses to the following question in the 1995 SCF: "People have different reasons for saving, even though they may not be saving all the time. What are your family's most important reasons for saving?" Percentages sum to more than 100 because some respondents provided more than one reason. 
Table A2: Explaining Desired Precautionary Savings: Main Sample

\begin{tabular}{|c|c|c|}
\hline Variables & Estimates (s.e.) & Estimates (s.e.) \\
\hline \multicolumn{3}{|l|}{ Risk and permanent income } \\
\hline State unemployment rate & $0.032(0.020)^{*}$ & $0.042(0.020)^{* *}$ \\
\hline Respondent has good idea of next year's income & $-0.120(0.045) * * *$ & $-0.124(0.044)^{* * *}$ \\
\hline State out-of-pocket health costs & $-0.000(0.000)$ & $-0.000(0.000)$ \\
\hline Future health expenditure & $0.201(0.057)^{* * *}$ & $0.230(0.057)^{* * *}$ \\
\hline Longevity risk & $2.903(0.762)^{* * *}$ & $3.043(0.759)^{* * *}$ \\
\hline Log of permanent income & $0.486(0.028)^{* * *}$ & $0.319(0.031)^{* * *}$ \\
\hline \multicolumn{3}{|l|}{ Macro shocks } \\
\hline Deviation from predicted wages & $0.038(0.012)^{* * *}$ & $0.024(0.012)^{* * *}$ \\
\hline Income lower than normal & $-0.044(0.054)$ & $-0.022(0.053)$ \\
\hline Income higher than normal & $0.120(0.065)^{* *}$ & $0.081(0.064)$ \\
\hline Year dummy & $0.094(0.074)$ & $0.074(0.074)$ \\
\hline \multicolumn{3}{|l|}{ Age and longevity } \\
\hline Age & $0.039(0.019) * *$ & $0.038(0.019) * *$ \\
\hline Age squared & $-0.029(0.023)$ & $-0.039(0.023)^{* *}$ \\
\hline Expected years left to live (max of head or spouse) & $-0.000(0.002)$ & $-0.001(0.002)$ \\
\hline \multicolumn{3}{|l|}{ Liquidity constraints } \\
\hline Household has a bank-type credit card & $0.160(0.057)^{* * *}$ & $0.131(0.057)^{* *}$ \\
\hline $\begin{array}{l}\text { Ratio of credit limit on all credit cards over permanent } \\
\text { income }\end{array}$ & $0.267(0.079)^{* * *}$ & $0.247(0.076)^{* * *}$ \\
\hline Credit limit/perm income * low income $(Y<25,000)$ & $-0.177(0.082)^{* *}$ & $-0.182(0.078)^{* * *}$ \\
\hline Ratio of debt on all credit cards over total credit limit & $-0.208(0.054) * * *$ & $-0.129(0.054)^{* * *}$ \\
\hline Total credit card debt/total limit * low income $(Y<25,000)$ & $0.206(0.058) * * *$ & $0.126(0.058)^{* *}$ \\
\hline Annualized payments on total loans over income & $0.092(0.033)^{* * *}$ & $0.066(0.034)^{* *}$ \\
\hline Percent of local banking mkt held by four largest banks & $-0.003(0.002)$ & $-0.003(0.001)^{* *}$ \\
\hline \multicolumn{3}{|l|}{ Future expenses } \\
\hline Household had education expenses in next 5-10 years & $-0.044(0.047)$ & $-0.051(0.047)$ \\
\hline Household has home expenses in next 5-10 years & $-0.063(0.044)^{*}$ & $-0.023(0.044)$ \\
\hline Households has other expenses in next 5-10 years & $0.126(0.145)$ & $0.107(0.142)$ \\
\hline \multicolumn{3}{|l|}{ Risk preferences } \\
\hline Unwilling to take any financial risk & $-0.075(0.050)^{*}$ & $-0.053(0.049)$ \\
\hline
\end{tabular}




\begin{tabular}{|c|c|c|}
\hline Willing to take above average risk for above average return & $0.014(0.053)$ & $-0.012(0.053)$ \\
\hline Willing to take large risk for large return & $-0.019(0.093)$ & $-0.064(0.093)$ \\
\hline \multicolumn{3}{|l|}{ Other preferences and attitudes toward savings } \\
\hline The head or spouse smoke & $-0.022(0.043)$ & $-0.002(0.043)$ \\
\hline Household has plan for saving & $0.123(0.042) * * *$ & $0.084(0.042)^{* *}$ \\
\hline Degree of shopping for returns on saving and investment & $0.032(0.015)^{* *}$ & $0.022(0.015)^{*}$ \\
\hline Expected interest rates in the next 5 years & $0.011(0.033)$ & $0.031(0.032)$ \\
\hline Adequacy of pensions/Social Securiy & $-0.044(0.017)^{* * *}$ & $-0.050(0.016) * * *$ \\
\hline It is import to leave an inheritance & $0.072(0.039)^{* *}$ & $0.047(0.039)$ \\
\hline At least one parent is alive & $0.029(0.070)$ & $0.049(0.068)$ \\
\hline \multicolumn{3}{|l|}{ Demographics } \\
\hline High school degree & $0.041(0.068)$ & $0.064(0.068)$ \\
\hline Some college & $0.129(0.074)^{* *}$ & $0.143(0.074)^{* *}$ \\
\hline College and more than college & $0.307(0.079) * * *$ & $0.304(0.079)^{* * *}$ \\
\hline Nonwhite or Hispanic & $0.001(0.068)$ & $0.022(0.068)$ \\
\hline Married & $0.007(0.073)$ & $0.012(0.073)$ \\
\hline Separated or divorced & $0.135(0.069)^{* *}$ & $0.164(0.069) * * *$ \\
\hline Widowed & $0.254(0.133)$ & $0.220(0.132)^{* *}$ \\
\hline Dummy if there are children younger than 18 & $-0.151(0.064) * * *$ & $-0.156(0.063) * * *$ \\
\hline Dummy if there are children between age 18-24 & $-0.057(0.018)^{* * *}$ & $-0.048(0.018)^{* * *}$ \\
\hline Dummy if there are children age 25 or older & $-0.042(0.029)^{*}$ & $-0.025(0.029)$ \\
\hline Household size & $0.038(0.024)^{*}$ & $0.036(0.024)^{*}$ \\
\hline \multicolumn{3}{|l|}{ Continuation } \\
\hline \multicolumn{3}{|l|}{ Other controls } \\
\hline Excellent health & $0.080(0.044)^{* *}$ & $0.066(0.043)^{*}$ \\
\hline Fair or poor health & $-0.090(0.057)^{*}$ & $-0.075(0.057)^{*}$ \\
\hline Constant & $0.880(0.529)^{* *}$ & $2.408(0.541)^{* * *}$ \\
\hline Wealth dummies & no & yes \\
\hline
\end{tabular}

Note: This table reports estimates of the regressions of the log of desired precautionary saving on the variables listed in the first column for the main sample. The number of observations is 4,105. “*”, “**, “***” indicate significance at the $10 \%, 5 \%$ and $1 \%$ level, respectively. 
Table A3: Explaining Desired Precautionary Savings - Older Sample

\begin{tabular}{|c|c|c|}
\hline Variables & Estimates (s.e.) & Estimates (s.e.) \\
\hline \multicolumn{3}{|l|}{ Risk and permanent income } \\
\hline State unemployment rate & $0.017(0.042)$ & $0.011(0.042)$ \\
\hline Respondent has good idea of next year's income & $-0.008(0.098)$ & $-0.024(0.096)$ \\
\hline State out-of-pocket health costs & $0.000(0.000)$ & $0.000(0.000)$ \\
\hline Future health expenditure & $0.365(0.099)^{* * *}$ & $0.369(0.095)^{* * *}$ \\
\hline Longevity risk & $5.410(1.728)^{* * *}$ & $5.409(1.660)^{* * *}$ \\
\hline Permanent income & $0.317(0.050) * * *$ & $0.137(0.050) * * *$ \\
\hline \multicolumn{3}{|l|}{ Macro shocks } \\
\hline Deviation from predicted wages & $-0.003(0.027)$ & $-0.001(0.026)$ \\
\hline Income lower than normal & $-0.097(0.149)$ & $0.020(0.148)$ \\
\hline Income higher than normal & $0.256(0.153)^{* *}$ & $0.194(0.150)^{*}$ \\
\hline Year dummy & $-0.127(0.161)$ & $-0.159(0.161)$ \\
\hline \multicolumn{3}{|l|}{ Age and longevity } \\
\hline Age & $0.070(0.091)$ & $0.040(0.089)$ \\
\hline Age squared & $-0.068(0.060)$ & $-0.050(0.059)$ \\
\hline Expected years left to live (max of head or spouse) & $0.000(0.006)$ & $0.004(0.006)$ \\
\hline \multicolumn{3}{|l|}{ Liquidity constraints } \\
\hline Household has a bank-type credit card & $0.223(0.114) * *$ & $0.138(0.115)$ \\
\hline Ratio of credit limit on all credit cards over permanent income & $0.009(0.099)$ & $-0.018(0.101)$ \\
\hline Credit limit/perm income * low income $(\mathrm{Y}<25,000)$ & $0.030(0.099)$ & $0.037(0.101)$ \\
\hline Ratio of debt on all credit cards over total credit limit & $-0.297(0.525)$ & $0.040(0.533)$ \\
\hline Total credit card debt/total limit * low income $(\mathrm{Y}<25,000)$ & $0.128(0.522)$ & $-0.148(0.530)$ \\
\hline Annualized payments on total loans over income & $0.126(0.211)$ & $-0.028(0.208)$ \\
\hline Percent of local banking mkt held by four largest banks & $0.002(0.003)$ & $0.003(0.003)$ \\
\hline \multicolumn{3}{|l|}{ Continuation } \\
\hline \multicolumn{3}{|l|}{ Future expenses } \\
\hline Household had education expenses in next 5-10 years & $0.286(0.216)^{*}$ & $0.235(0.217)$ \\
\hline Household has home expenses in next 5-10 years & $0.191(0.155)$ & $0.210(0.149)^{*}$ \\
\hline Households has other expenses in next 5-10 years & $-0.140(0.257)$ & $-0.128(0.248)$ \\
\hline \multicolumn{3}{|l|}{ Risk preferences } \\
\hline Unwilling to take any financial risk & $-0.164(0.099)^{* *}$ & $-0.037(0.102)$ \\
\hline
\end{tabular}




\begin{tabular}{|c|c|c|}
\hline $\begin{array}{l}\text { Willing to take above average or larger risk for above average } \\
\text { or large return }\end{array}$ & $-0.032(0.132)$ & $-0.040(0.130)$ \\
\hline \multicolumn{3}{|l|}{ Other preferences and attitudes toward savings } \\
\hline The head or spouse smoke & $-0.024(0.109)$ & $0.024(0.106)$ \\
\hline Household has plan for saving & $0.073(0.088)$ & $0.040(0.087)$ \\
\hline Degree of shopping for returns on saving and investment & $0.077(0.032)^{* * *}$ & $0.062(0.031)^{* * *}$ \\
\hline Expected interest rates in the next 5 years & $0.054(0.067)$ & $0.070(0.065)$ \\
\hline Adequacy of pensions/Social Securiy & $-0.001(0.031)$ & $0.003(0.030)$ \\
\hline It is import to leave an inheritance & $0.169(0.084)^{* *}$ & $0.117(0.081)^{*}$ \\
\hline At least one parent is alive & $-0.104(0.117)$ & $-0.111(0.117)$ \\
\hline \multicolumn{3}{|l|}{ Demographics } \\
\hline High school degree & $0.175(0.113)^{*}$ & $0.047(0.111)$ \\
\hline Some college & $0.385(0.135) * * *$ & $0.282(0.131)^{* *}$ \\
\hline College and more than college & $0.602(0.140)^{* * *}$ & $0.431(0.135)^{* * *}$ \\
\hline Nonwhite or Hispanic & $-0.662(0.168) * * *$ & $0.519(0.165)^{* * *}$ \\
\hline Married & $0.007(0.245)$ & $-0.016(0.240)$ \\
\hline Separated or divorced & $-0.027(0.229)$ & $0.140(0.232)$ \\
\hline Widowed & $-0.157(0.208)$ & $-0.120(0.206)$ \\
\hline Dummy if there are children younger than 18 & $-0.201(0.302)$ & $-0280(0.295)$ \\
\hline Dummy if there are children between age 18-24 & $-0.024(0.021)$ & $-0.017(0.020)$ \\
\hline Dummy if there are children age 25 or older & $-0.058(0.063)$ & $-0.050(0.064)$ \\
\hline Household size & $-0.057(0.125)$ & $-0.044(0.123)$ \\
\hline \multicolumn{3}{|l|}{ Continuation } \\
\hline \multicolumn{3}{|l|}{ Other controls } \\
\hline Excellent health & $0.182(0.115)^{*}$ & $0.189(0.112)^{* *}$ \\
\hline Fair or poor health & $-0.142(0.091) *$ & $0.055(0.088)$ \\
\hline Constant & $0.446(3.399)$ & $2.594(3.339)$ \\
\hline Wealth dummies & no & yes \\
\hline
\end{tabular}

Note: This table reports estimates of the regressions of the log of desired precautionary saving on the variables listed in the first column for the older sample. The number of observations is 1,634. “*”, “**, “***” indicate significance at the $10 \%, 5 \%$ and $1 \%$ level, respectively. 
Table A4: Explaining Desired Precautionary Savings - Business Sample

\begin{tabular}{|c|c|c|}
\hline Variables & Estimates (s.e.) & Estimates (s.e.) \\
\hline \multicolumn{3}{|l|}{ Risk and permanent income } \\
\hline State unemployment rate & $0.055(0.030)^{* *}$ & $0.053(0.029)^{* *}$ \\
\hline Respondent has good idea of next year's income & $-0.032(0.065)$ & $-0.032(0.065)$ \\
\hline State failure rate of businesses of same type and age & $0.010(0.018)$ & $0.011(0.018)$ \\
\hline Head works in the actively managed firm owned by family & $-0.025(0.114)$ & $-0.035(0.113)$ \\
\hline Spouse works in the actively managed firm owned by family & $0.004(0.073)$ & $0.003(0.073)$ \\
\hline Family own 2 businesses they actively manage & $-0.008(0.082)$ & $-0.042(0.082)$ \\
\hline Family own more than 2 businesses they actively manage & $0.419(0.096)^{* * *}$ & $0.304(0.099) * * *$ \\
\hline State out-of-pocket health costs & $0.000(0.000)$ & $-0.000(0.000)$ \\
\hline Future health expenditure & $0.184(0.093)^{* *}$ & $0.203(0.093)^{* *}$ \\
\hline Longevity risk & $1.471(1.907)$ & $1.140(1.856)$ \\
\hline Log of permanent income & $0.449(0.031)^{* * *}$ & $0.360(0.034) * * *$ \\
\hline \multicolumn{3}{|l|}{ Macro shocks } \\
\hline Deviation from predicted wages & $0.048(0.016) * * *$ & $0.043(0.015)^{* * *}$ \\
\hline Income lower than normal & $0.037(0.094)$ & $0.052(0.091)$ \\
\hline Income higher than normal & $0.160(0.088)^{* *}$ & $0.123(0.090)^{*}$ \\
\hline Year dummy & $0.008(0.125)$ & $0.016(0.126)$ \\
\hline \multicolumn{3}{|l|}{ Age and longevity } \\
\hline Age & $0.069(0.019) * * *$ & $0.067(0.019) * * *$ \\
\hline Age squared & $-0.048(0.019)^{* * *}$ & $-0.049(0.019)^{* * *}$ \\
\hline Expected years left to live (max of head or spouse) & $0.005(0.003)^{*}$ & $0.005(0.003)$ \\
\hline \multicolumn{3}{|l|}{ Liquidity constraints } \\
\hline Household has a bank-type credit card & $0.007(0.129)$ & $-0.002(0.129)$ \\
\hline $\begin{array}{l}\text { Ratio of credit limit on all credit cards over permanent } \\
\text { income }\end{array}$ & $0.518(0.118)^{* * *}$ & $0.525(0.117)^{* * *}$ \\
\hline Credit limit/perm income * low income $(\mathrm{Y}<25,000)$ & $-0.493(0.117) * * *$ & $-0.503(0.116) * * *$ \\
\hline Ratio of debt on all credit cards over total credit limit & $-0.011(0.010)$ & $-0.012(0.010)$ \\
\hline Total credit card debt/total limit * low income $(\mathrm{Y}<25,000)$ & $0.435(0.401)$ & $0.357(0.395)$ \\
\hline Annualized payments on total loans over income & $0.002(0.001)^{*}$ & $0.001(0.001)$ \\
\hline Percent of local banking mkt held by four largest banks & $-0.004(0.003)^{* *}$ & $-0.004(0.003)^{*}$ \\
\hline \multicolumn{3}{|l|}{ Future expenses } \\
\hline Household had education expenses in next 5-10 years & $0.067(0.078)$ & $0.053(0.077)$ \\
\hline Household has home expenses in next $5-10$ years & $0.004(0.081)$ & $0.021(0.082)$ \\
\hline
\end{tabular}




\begin{tabular}{|c|c|c|}
\hline Households has other expenses in next 5-10 years & $-0.079(0.176)$ & $-0.164(0.175)$ \\
\hline \multicolumn{3}{|l|}{ Risk preferences } \\
\hline Unwilling to take any financial risk & $-0.067(0.103)$ & $-0.067(0.102)$ \\
\hline Willing to take above average risk for above average return & $0.036(0.068)$ & $0.020(0.068)$ \\
\hline Willing to take large risk for large return & $0.111(0.111)$ & $0.073(0.110)$ \\
\hline \multicolumn{3}{|l|}{ Other preferences and attitudes toward savings } \\
\hline The head or spouse smoke & $0.026(0.076)$ & $0.033(0.076)$ \\
\hline Household has plan for saving & $0.026(0.062)$ & $0.014(0.062)$ \\
\hline Degree of shopping for returns on saving and investment & $0.058(0.021) * * *$ & $0.047(0.021)^{* *}$ \\
\hline Expected interest rates in the next 5 years & $0.015(0.048)$ & $0.005(0.047)$ \\
\hline Adequacy of pensions/Social Securiy & $-0.048(0.021) * *$ & $-0.0490 .021)^{* * *}$ \\
\hline It is import to leave an inheritance & $0.109(0.066)^{* *}$ & $0.071(0.066)$ \\
\hline At least one parent is alive & $-0.146(0.105)^{*}$ & $-0.131(0.103)$ \\
\hline \multicolumn{3}{|l|}{ Demographics } \\
\hline High school degree & $-0.108(0.167)$ & $-0.117(0.167)$ \\
\hline Some college & $-0.171(0.167)$ & $-0.180(0.166)$ \\
\hline College and other non-professional degrees & $-0.020(0.166)$ & $-0.066(0.166)$ \\
\hline Head or spouse has MBA & $0.213(0.137) *$ & $0.172(0.135)$ \\
\hline Head or spouse has other professional degree (JD, MD,...) & $0.129(0.112)$ & $0.133(0.111)$ \\
\hline Nonwhite or Hispanic & $-0.017(0.160)$ & $0.037(0.159)$ \\
\hline Married & $-0.161(0.182)$ & $-0.122(0.180)$ \\
\hline Separated or divorced & $-0.077(0.185)$ & $0.184(0.265)$ \\
\hline Widowed & $0.175(0.270)$ & $0.265(0.274)$ \\
\hline Dummy if there are children younger than 18 & $-0.022(0.113)$ & $-0.010(0.112)$ \\
\hline Dummy if there are children between age $18-24$ & $-0.002(0.024)$ & $-0.000(0.024)$ \\
\hline Dummy if there are children age 25 or older & $-0.060(0.040)^{*}$ & $-0.046(0.040)$ \\
\hline Household size & $0.001(0.042)$ & $0.004(0.041)$ \\
\hline \multicolumn{3}{|l|}{ Other controls } \\
\hline Excellent health & $0.087(0.066)^{* *}$ & $0.074(0.066)$ \\
\hline Fair or poor health & $0.034(0.107)$ & $0.028(0.110)$ \\
\hline Constant & $1.238(0.807)^{*}$ & $2.359(0.817)^{* * *}$ \\
\hline Wealth dummies & no & yes \\
\hline Controls for business size and type & yes & yes \\
\hline
\end{tabular}

Note: This table reports estimates of the regressions of the log of desired precautionary saving on the variables listed in the first column for the business sample. The number of observations is 2,236 . "*”, “**, “***” indicate significance at the $10 \%, 5 \%$ and $1 \%$ level, respectively. 
Figure 1: Density estimate of desired precautionary savings; 1995 SCF; 1995 dollars.

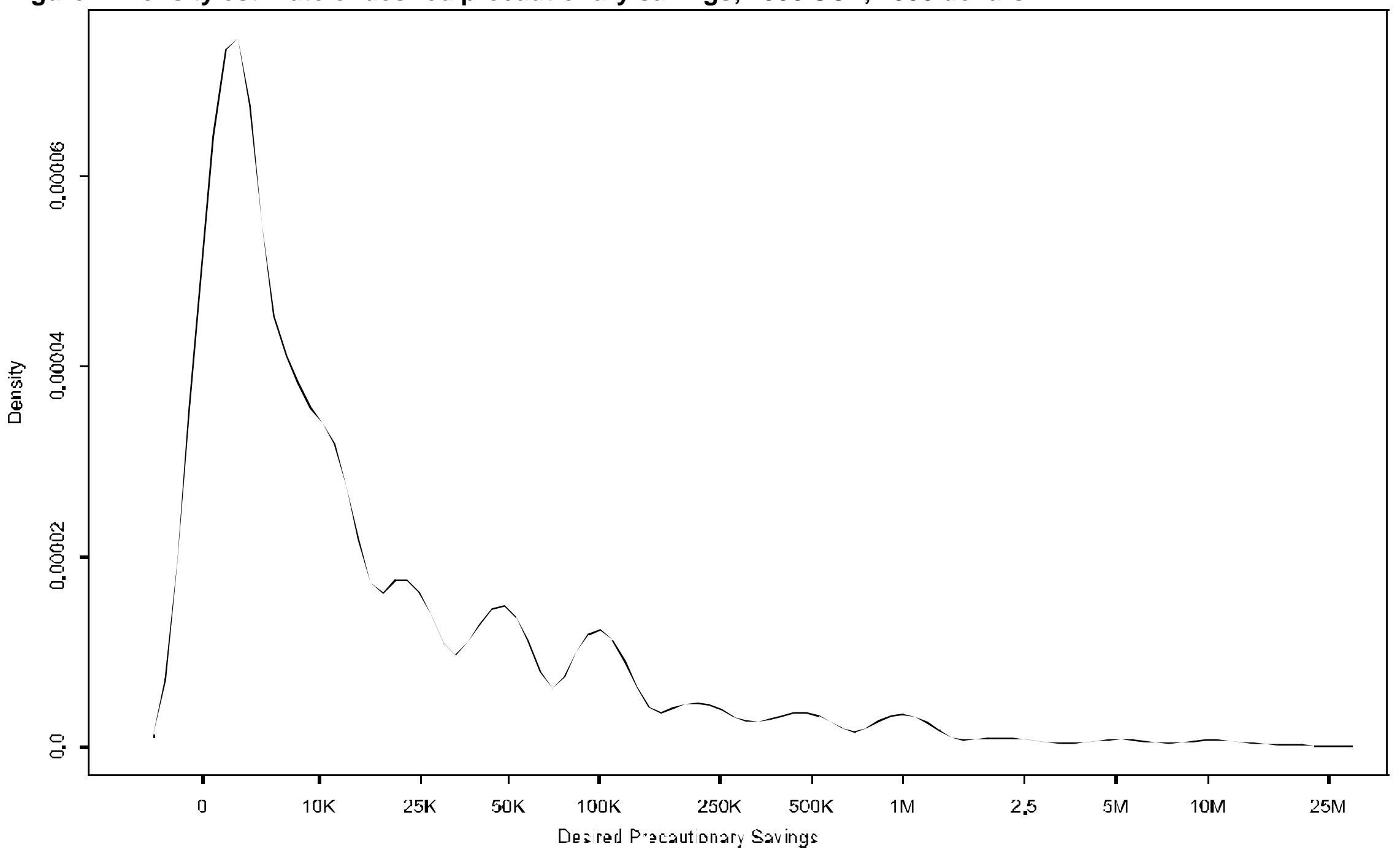


Figure 2: Density estimates of desired precautionary savings; 1995 and 1998 SCF; 1995 dollars.

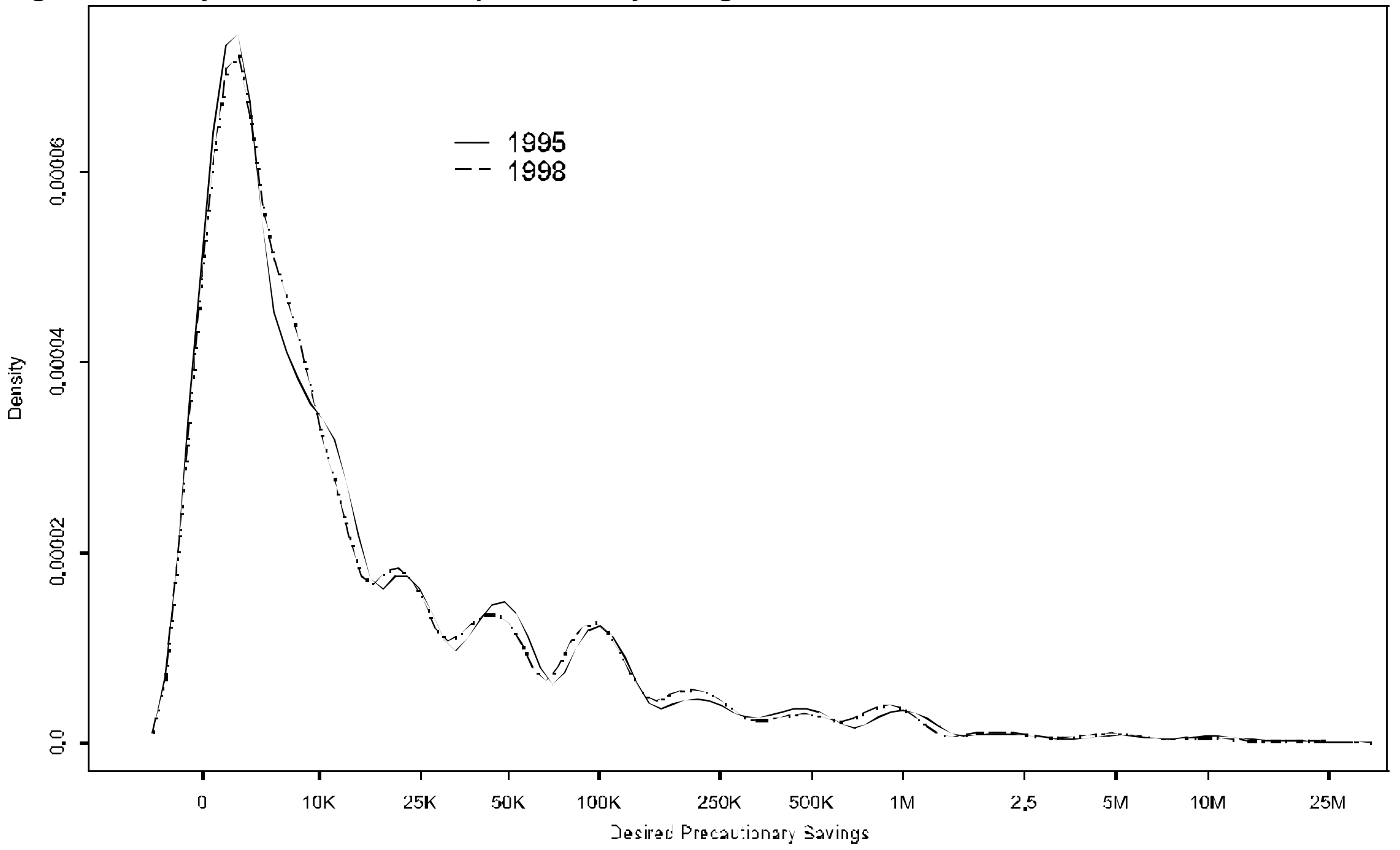


Figure 3a: Conditional distribution of desired precautionary savings, by age of the head of the household; $10^{\text {th }}$, $25^{\text {th }}, 50^{\text {th }}, 75^{\text {th }}$, and $90^{\text {th }}$ percentiles of the distribution; sample with household heads having less than 12 years of formal education; 1995 and 1998 SCF; 1995 dollars.

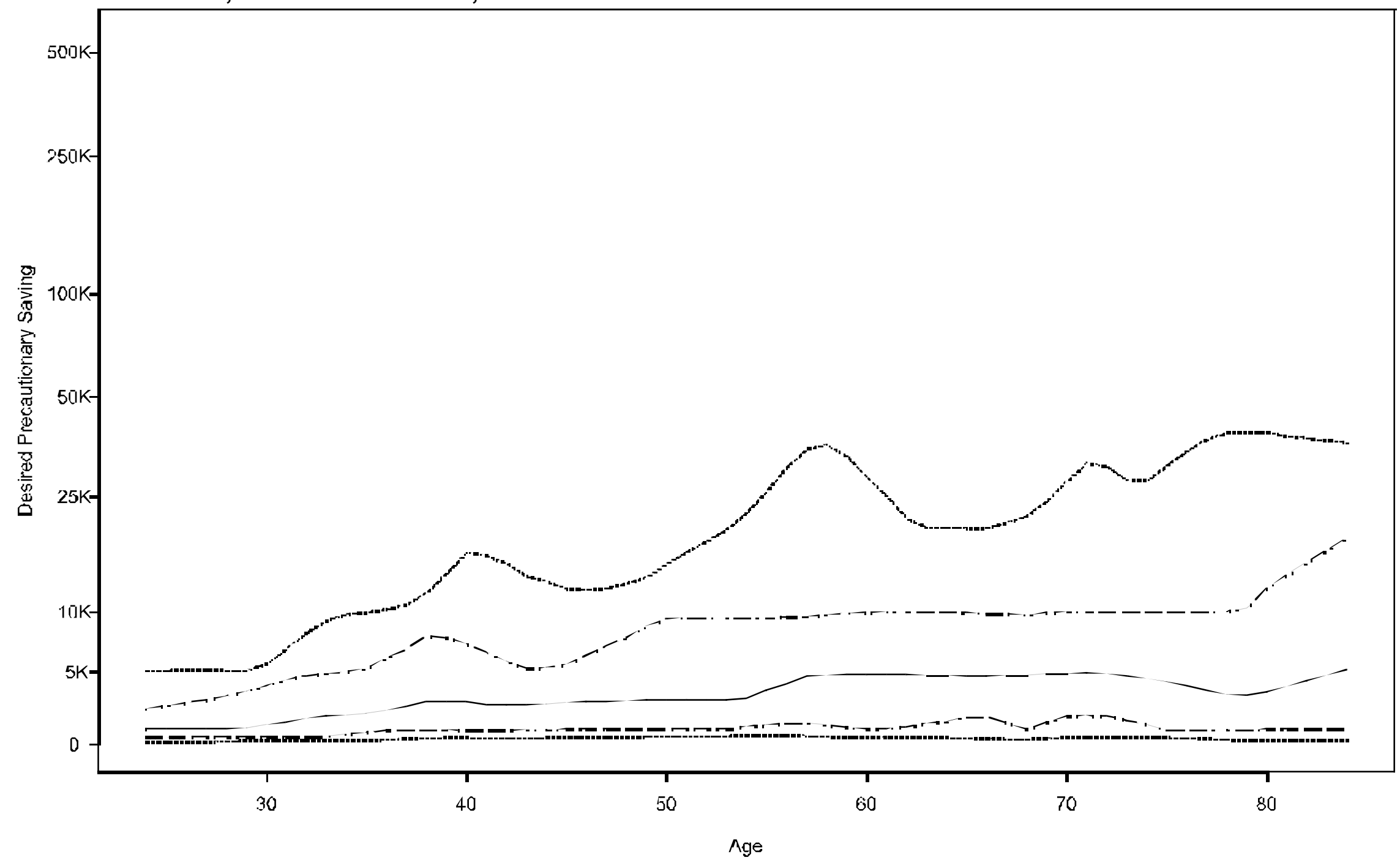


Figure 3b: Conditional distribution of desired precautionary savings, by age of the head of the household; $10^{\text {th }}$, $25^{\text {th }}, 50^{\text {th }}, 75^{\text {th }}$, and $90^{\text {th }}$ percentiles of the distribution; sample with household heads having 12 to 15 years of formal education; 1995 and 1998 SCF; 1995 dollars.

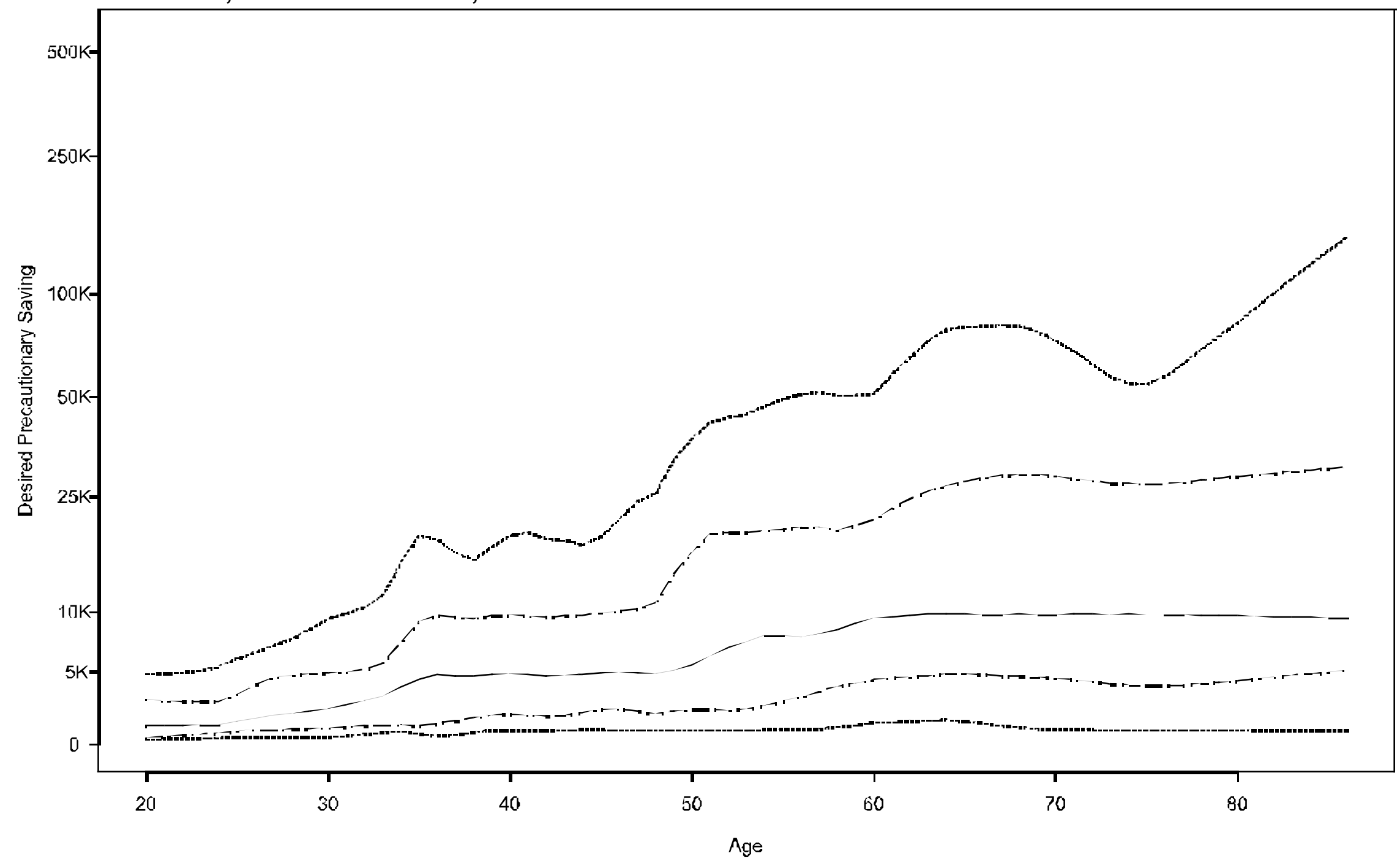


Figure 3c: Conditional distribution of desired precautionary savings, by age of the head of the household; $10^{\text {th }}$, $25^{\text {th }}, 50^{\text {th }}, 75^{\text {th }}$, and $90^{\text {th }}$ percentiles of the distribution; sample with household heads having 16 or more years of formal education; 1995 and 1998 SCF; 1995 dollars.

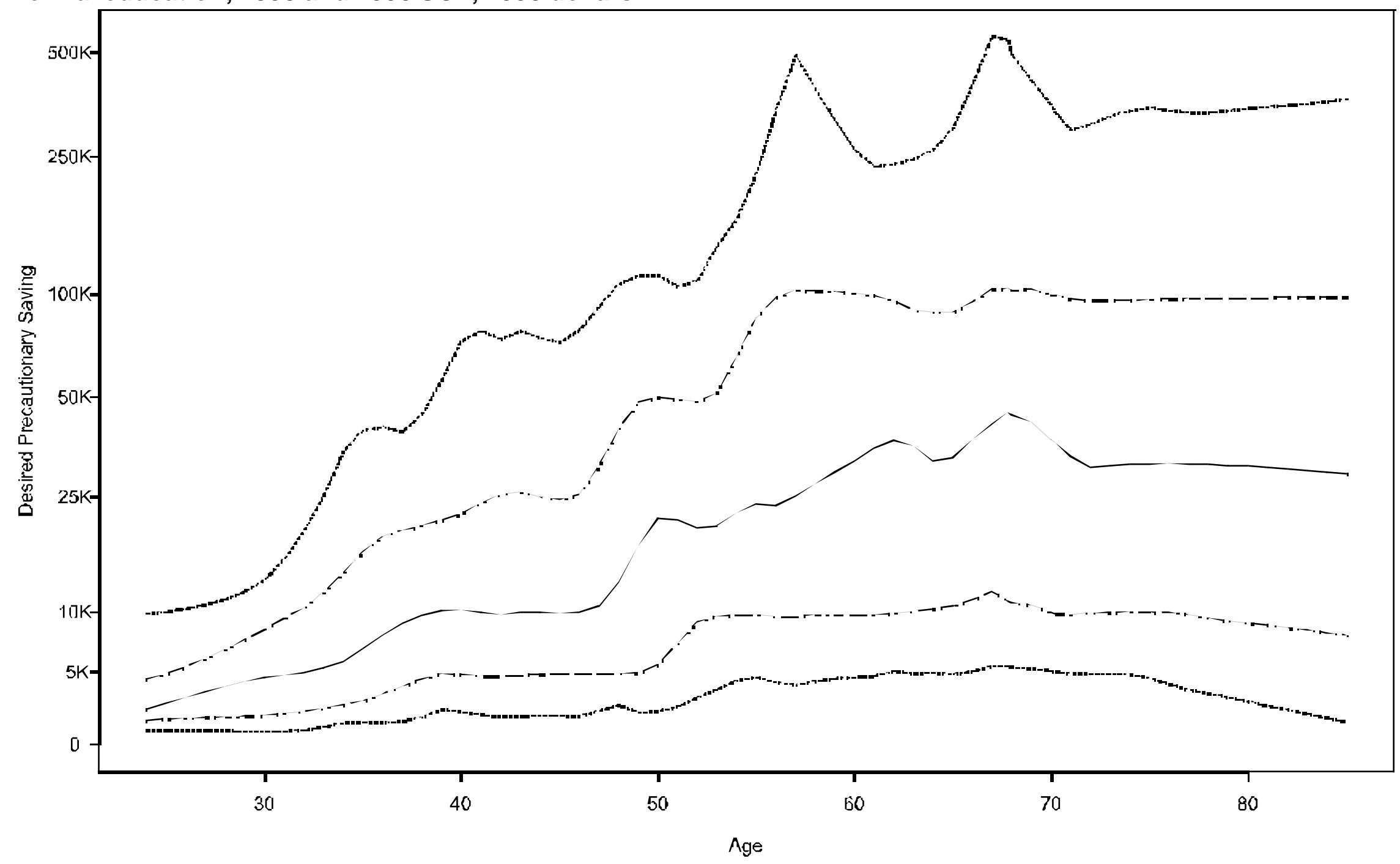


Figure 4: Density estimate of desired precautionary savings; full sample, main sample, older sample, and business sample; 1995 and 1998 SCF; 1995 dollars.

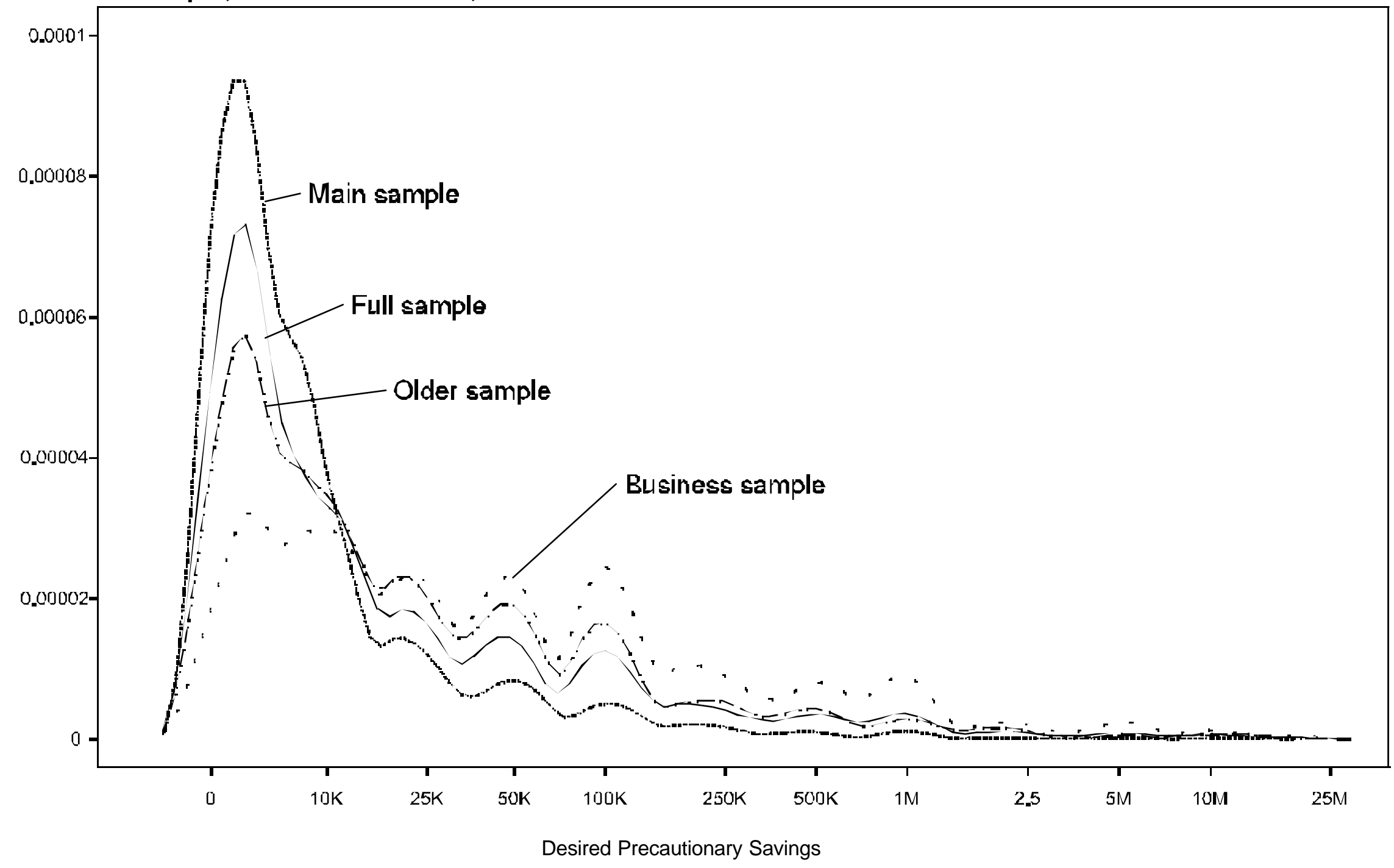


Figure 5: Density of the ratio of desired precautionary savings to normal income; full sample, main sample, older sample, and business sample; 1995 and 1998 SCF.

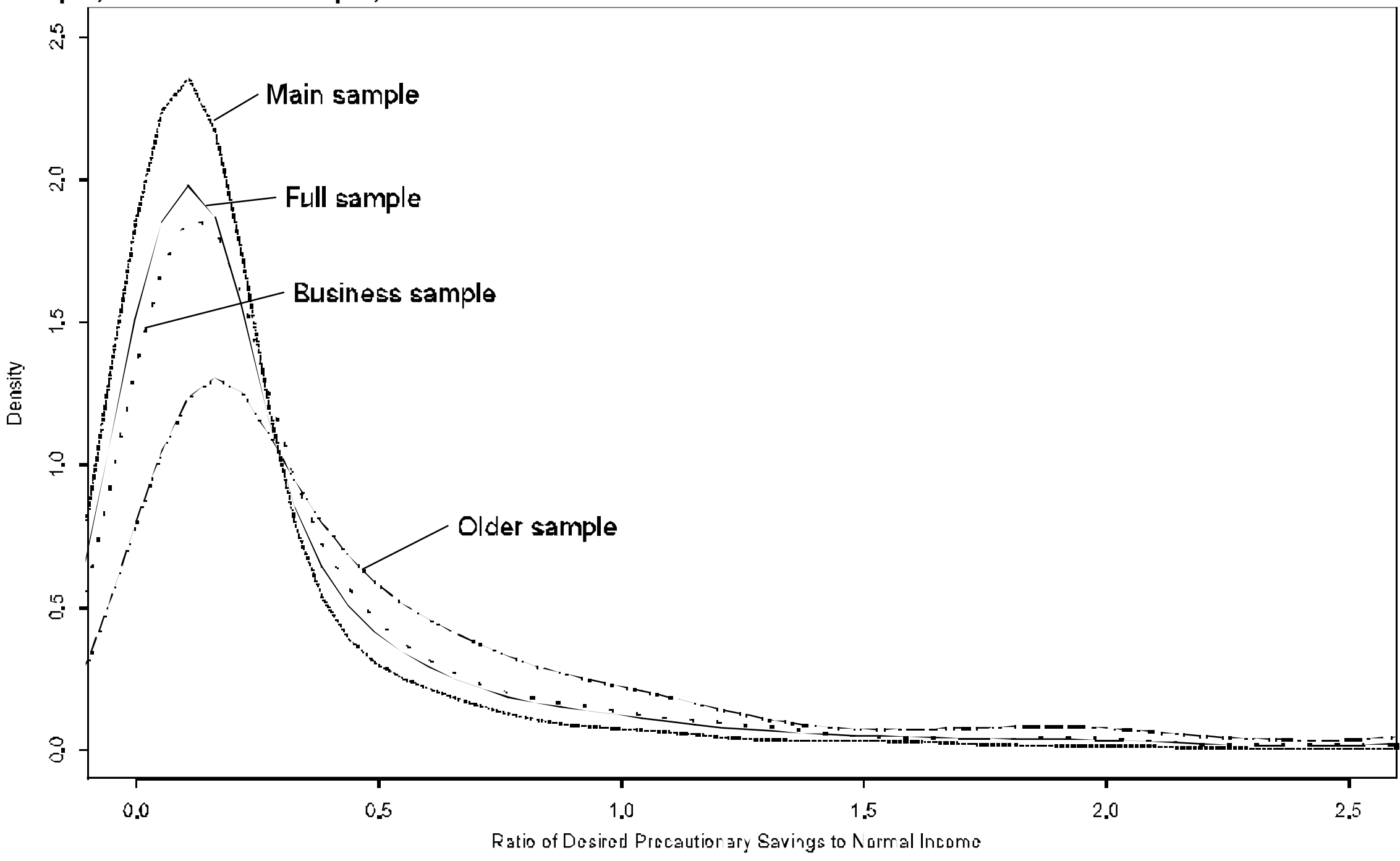

